San Jose State University

SJSU ScholarWorks

Master's Theses

Master's Theses and Graduate Research

1991

\title{
The effects of light, rearing density and formulated feeds on growth in the juvenile red abalone (Haliotis rufescens)
}

Jennifer Lea Greenier

San Jose State University

Follow this and additional works at: https://scholarworks.sjsu.edu/etd_theses

\section{Recommended Citation}

Greenier, Jennifer Lea, "The effects of light, rearing density and formulated feeds on growth in the juvenile red abalone (Haliotis rufescens)" (1991). Master's Theses. 197.

DOI: https://doi.org/10.31979/etd.b54u-qz7p

https://scholarworks.sjsu.edu/etd_theses/197

This Thesis is brought to you for free and open access by the Master's Theses and Graduate Research at SJSU ScholarWorks. It has been accepted for inclusion in Master's Theses by an authorized administrator of SJSU ScholarWorks. For more information, please contact scholarworks@sjsu.edu. 


\section{INFORMATION TG USERS}

This manuscript has been reproduced from the microfilm master. UMI films the text directly from the original or copy submitted. Thus, some thesis and dissertation copies are in typewriter face, while others may be from any type of computer printer.

The quality of this reproduction is dependent upon the quality of the copy submitted. Broken or indistinct print, colored or poor quality illustrations and photographs, print bleedthrough, substandard margins, and improper alignment can adversely affect reproduction.

In the unlikely event that the author did not send UMI a complete manuscript and there are missing pages, these will be noted. Also, if unauthorized copyright material had to be removed, a note will indicate the deletion.

Oversize materials (e.g., maps, drawings, charts) are reproduced by sectioning the original, beginning at the upper left-hand corner and continuing from left to right in equal sections with small overlaps. Each original is also photographed in one exposure and is included in reduced form at the back of the book.

Photographs included in the original manuscript have been reproduced xerographically in this copy. Higher quality 6" $\mathrm{n} 9$ " black and white photographic prints are available for any photographs or illustrations appearing in this copy for an additional charge. Contact UMII directly to order.

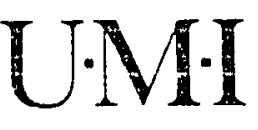

University Microfilms International

A Beil \& Howell Iniormation Company 300 North Zeeb Road. Ann Arbor. MI 48106-1346 USA

$313,761-4700 \quad 800,521.0600$ 

The effects of light, rearing density and formulated feeds on growth in the juvenile red abalone (Haliotis rufescens)

Greenier, Jennifer Lea, M.S.

San Jose State University, 1991 


\author{
THE EFFECTS OF LIGHT, REARING DENSITY \\ AND FORMULATED FEEDS ON GROWTH IN THE \\ JUVENILE RED ABALONE (HALIOTIS RUFESCENS)
}

\begin{abstract}
A Thesis
Presented to

The Faculty and Department of Marine Science

Moss Landing Marine Laboratories

San Jose State University
\end{abstract}

\author{
In Partial Fulfillment \\ of the Requirements for the Degree \\ Master of Science
}

By

Jennifer Lea Greenier

May, 1991 


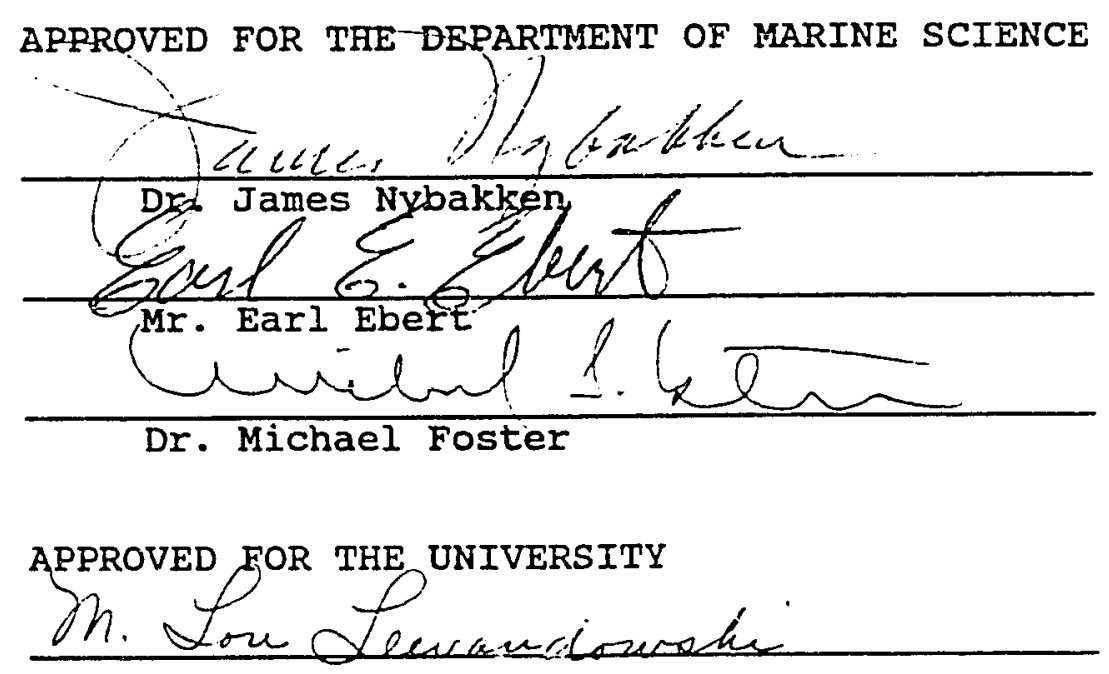


ABSTRACT

THE EFFECTS OF LIGHT, REARING DENSITY

AND FORMULATED DIETS ON GROWTH IN THE

JUVENILE RED ABALONE (HALIOTIS RUFESCENS)

by Jennifer L. Greenier

Experiments were conducted to determine the effects of light, rearing density, and diet on growth in juvenile red abalone, Haliotis rufescens. In Part $I$, abalone were subjected to 3 light treatments--natural photoperiod, fluorescent light, and complete darkness, and 3 density levels-high (1420 individuals $\left./ \mathrm{m}^{2}\right)$, medium $\left(568 / \mathrm{m}^{2}\right)$, and low $\left(189 / \mathrm{m}^{2}\right)$ for 6 months. A significant interaction ( $\underline{\mathrm{P}}=$ 0.0283 ) was found between density and light. Examination of treatment means revealed higher growth rates for abalone at low densities under all light conditions, and in dark conditions at all density levels. Three mathematical growth models, logistic, Gompertz, and von Bertalanffy, were fit to the growth data using nonlinear regression in Part II. The von Bertalanffy was chosen as the best-fitting model because it had the smallest residual error (0.19). In Part III, 3 groups of abalone were maintained on a kelp diet and 2 formulated feed diets. Abalone grew equally well on all 3 diets. 
PREFACE

I have chosen to write my thesis following the format of the journal Aquaculture. My thesis consists of 3 papers resulting from 2 experiments. The first paper examines the effects of light and rearing density on growth in juyenile abalone. The second paper discusses the application of various growth models to observed measurement data. The final paper describes an experiment designed to test the efficacy of a formulated feed diet for red abalone. 
PART ONE

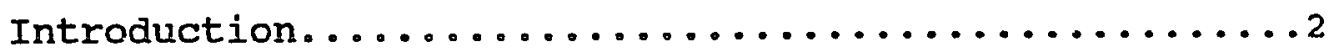

Materials and Methods......................

Results..............................

Discussion............................... 10

Literature cited.......................... 15

Tables................................ 20

Figures................................ 27

PART II

Introduction. ............................

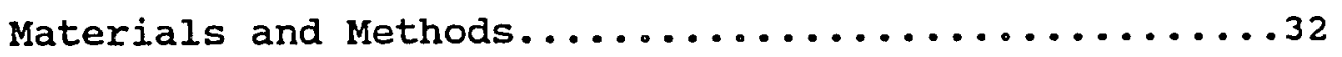

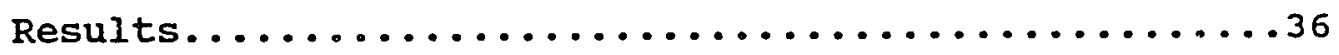

Discussion.................................... 38

Literature cited........................4

Tables............................... 46

Figures................................ 51

PART III

Introduction.......................... 56

Materials and Methods....................57

Results..............................60

Discussion............................. 61 
MABLE OF CONTENTS, cont.

Literature cited......................65

Tables............................... 68

Figures................................ 71

ACKNOWLEDGEMENTS. . . . . . . . . . . . . . . . . . 72 


\section{IIST OF TABLES}

Page

Part I

Table 1: Growth under various light conditions.....20

Table 2: Growth at various densities............21

Table 3: Analysis of variance table (I) ..........22

Table 4: Growth under treatment combinations.......23

Table 5: Growth under different handling treatments..24

Table 6: Analysis of variance table (II) ..........25

Table 7: Growth to market size estimates..........26

Part II

Table 1: Correlation of growth variables..........46

Table 2: Mean growth of abalone............... 47

Table 3: Comparison of growth models............48

Table $4:$ Growth model parameters...............49

Table 5: Mean feeding rate and feed conversion......50

Part III

Table 1: Growth of abalone on various diets.......68

Table 2: Correlation of growth variables..........69

Table 3: Analysis of variance table.............70 
PART I

The Effect of Light and Rearing Density on Growth in Juvenile Red Abalone 


\section{INTRODUCTION}

The red abalone, Haliotis rufescens, has been esteemed as an important commercial species and a culinary delicacy in California since the early 1900s (Howorth, 1988). Its status as the principal sport and commercial abalone species for the west coast is attributed to its large size and high quality meat. Abalone were heavily exploited for several decades yielding substantial annual catches. From 19601975, however, abalone landings decreased by $80 \%$ (Morse, 1984). Over harvesting by commercial and sport fisherman, loss of habitat due to pollution of coastal waters, and the resurgence of the sea otter, a major predator, caused a serious depletion of abalone populations. The disappearance of wild abalone resources sparked an interest in the development of the red abalone as an aquaculture species.

By the mid 1970s, several advances had been made in the cultivation of the red abalone (Fbert and Houk, 1984; Hahn, 1989). Further refinement of culture techniques and the development of a restaurant market for small-sized abalone have resulted in the success of abalone farmers along the California coast.

Economic success in the production of the red abalone is limited by the slow growth rate of this animal. Enhancing juvenile growth is a primary concern of abalone 
culturists. This is achieved largely by manipulating environmental factors to provide optimal growing conditions (Leighton, 1972; Chen, 1984). Rearing density and light exposure are 2 factors that may have an important affect on growth in young abalone (Shibui, 1972; Koike, 1979; Uki, 1981; 0lsen, 1982). Stocking density has been shown to affect growth in other molluscs (Hadley and Manzi, 1982; Kline, 1982; Woon, 1983; Manzi et al., 1986) and growth and survivorship in abalone during the larval stage (Ino, 1952; Shibui, 1972; Hooker and Morse, 1984). Information regarding density levels in juvenile abalone is sparse, and what literature does exist concerns abalone species cultured in Japan (Shibui, 1972; Koike et al., 1979; Chen, 1984).

In the cultivation of abalone, photoperiod is often manipulated to condition mature adults for spawning (Kanno, 1975; Ebert and Houk, 1984). Because feeding activity in abalone, a nocturnal species, is suppressed by high illumination (Shibui, 1972; Uki, 1981), light exposure could considerably affect growth rate as well.

This research addressed the question of how rearing density and light exposure influence the growth rate of juvenile red abalone. Abalone were maintained under various density and light conditions and measured to assess the effect of these factors on growth. 
Recent research by one investigator indicated that abalone suffer a handling stress due to researcher disturbance (E. Ebert, California Department of Fish and Game, unpublished data). This stress was manifested in a marked decline in feeding efficiency observed in the first few days after measurements were taken. Cultivation practices which require frequent handing of juvenile abalone may be detrimental to growth. A control group of abalone, measured only at the beginning and end of the experimental period, was included in this study to determine the effect of frequent handling on juvenile abalone growth.

\section{MATERIAIS AND METHODS}

\section{Location and Experimental Conditions}

Research was conducted at Granite Canyon Marine Resources Laboratory, a California Department of Fish and Game facility located 7 miles south of Carmel, california from November 1988 to April 1989. Thirty-three week old juvenile red abalone spawned from laboratory broodstock were used as experimental animals. The experiment was conducted in a rectangular water table $(2.17 \mathrm{~m} \times 0.90 \mathrm{~m} \times 0.25 \mathrm{~m})$ furnished with filtered $(1.00 \mu \mathrm{M})$ seawater which was pumped through a $5.00 \mathrm{~cm}$ (inside diameter) pipe and distributed via a manifold constructed of PVC pipe $12.54 \mathrm{~cm}$ inside 
diameter). A series of water valves connected to the manifold delivered water to the treatment containers. Black plastic partitions were used to separate treatment groups along the water table. Cylindrical plastic containers $(14.00 \mathrm{~cm}$ inside diameter $\mathrm{x} 12.00 \mathrm{~cm}$ in height) served as experimental vessels. Container lids were perforated around the edge ( $85.00 \mathrm{~mm}$ holes) with a central hole to accommodate a water inlet tube $(1.00 \mathrm{~cm}$ inside diameter). Water was supplied to each container at a flow rate of $1.5 \pm 0.51 / \mathrm{min}$ and at a temperature of $15^{\circ} \mathrm{C} \pm 0.5^{\circ} \mathrm{C}$. Containers were individually aerated with air stones connected to $4.00 \mathrm{~mm}$ Tygon ${ }^{R}$ tubing which was attached to an air supply manifold. Abalone were provided with an ad libitum diet of macroalgae (Macrocystis spp.) throughout the experiment. Each week, any remaining kelp or diatom growth was removed and all containers were rinsed and stocked with fresh food.

Abalone were stocked at 3 densities: low (L:189/ $\mathrm{m}^{2}$ ), medium $\left(M: 568 / \mathrm{m}^{2}\right)$, and high $\left(\mathrm{H}: 1420 / \mathrm{m}^{2}\right)$, represented by 10 , 30, and 75 abajone per container. They were also subjected to the following light treatments: natural light (s)-sunlight filtered through a roof of translucent fiberglass panels; artificial light (F)--fluorescent light (Chroma-50; Westinghouse, Inc. ${ }^{R}$ ) from a fixture positioned $1 \mathrm{~m}$ above the 
containers, and programmed (Micronta Programmable Timer ${ }^{R}$ ) to simulate natural photoperiod; and no light (D) $--24 \mathrm{~h}$ darkness. Mean light intensity readings (LI-COR Quantum/Radiometer/Photometer ${ }^{R}$ ) taken on a sunny day in each of the light treatment areas were $122,0.62$, and $0 \mu \mathrm{E} \mathrm{s} \mathrm{s}^{-1} \mathrm{~m}^{-2}$ for natural light, fluorescent light and no light, respectively.

The experimental unit was defined as a single container, subjected to 1 of 9 density and light treatment combinations. Individual abalone within each container were treated as repeated measures (Hurlbert, 1984), and their growth measurements were averaged to yield a value for each container. Treatment combinations were randomly assigned to containers and density treatments were randomly positioned within each light section along the water table. Treatment combinations were replicated 3 times.

\section{Growth Measurements}

Growth measurements (shell length, shell width, wet body weight) of all abalone were taken once every 3 weeks throughout the 6-month experimental period. Length and weight measurements were made with vernier calipers and recorded to the nearest $0.05 \mathrm{~mm}$. Abalone weight was measured with a Mettler digital balance to $0.01 \mathrm{~g}$. 
Control Animals

In order to assess the effect of handling on growth, 1 group of abalone was maintained in darkness and measured only at the beginning and end of the experiment. This control group consisted of 9 test containers, representing 3 replicates of each of the 3 density levels, high, medium and low. Containers in the control group were randomly interspersed among the previously described dark treatment group, comprised of abalone subjected to periodic measurement.

\section{Statistical Analysis}

A factorial analysis of variance (ANOVA: Zar, 1984;

SAS, 1988) was conducted to determine the effect of density and light treatments on growth, and to test for interaction between these 2 factors. Homogeneity of variances was examined with a variance ratio test (zar, 1984). Since measurements were taken from the same animals at each time period, the measurements were not independent (Underwood, 1981; SAS, 1988). To account for this correlation, a repeated measures ANOVA was performed (Cole and Grizzle, 1966; Winer, 1971; LaTour and Miniard, 1983). This procedure includes the factor, time, in the analysis, and treats measurements from each sample period as different 
levels of that factor (SAS, 1988). Repeated measures analyses test within-subject effects as well as the betweensubject effects (SAS, 1988). In addition, interactions between within-subjects and between-subjects factors are evaluated.

A single factor ANOVA was run to determine the effect of handling on growth. All ANOVA tests were deemed significant at $\underline{\mathrm{P}} \leq 0.05$. Finally, Pearson correlation (r:SAS, 1988) analyses were conducted to determine the relationship among growth parameters (length, width and weight). Correlation analyses could not be performed on all sample periods since the measurements were not independent. Therefore, Pearson correlations were only run on observations from the last measurement period.

\section{RESULTS}

Anályses were conducted on length measurements only, since growth parameters were highly correlated (length vs. width, $\underline{\underline{r}}=0.98$; length vs. weight, $\underline{\underline{r}}=0.96$; width vs. weight, $\underline{x}=0.96)$. At the end of the 6 -month experimental period, mean increases in shell length among the 3 light treatments were very similar when averaged over all density levels: $S=7.33 \mathrm{~mm} ; \underline{F}=8.95 \mathrm{~mm} ;$ and $\mathrm{D}=8.95 \mathrm{~mm}$ (Table 1, Figure 1). Greater differences among density treatments 
were observed when mean increases in shell length were averaged over all light levels: $H=7.10 \mathrm{~mm} ; \mathrm{M}=10.01 \mathrm{~mm}$; $\mathrm{I}$ $=11.59 \mathrm{~mm}$ (Table 2, Figure 2). A variance ratio test indicated that treatment variances were not significantly different $(\underline{F}=1.47, \underline{P}=0.2)$.

The results of the repeated measures ANOVA (Table 3) indicated no significant differences among light treatments $(\underline{P}=0.12)$, but highly significant differences among density treatments $(\underline{P}=0.0001)$. However, there was a significant interaction between the main effects $(\underline{P}=0.0283)$, confounding the results.

Examination of the treatment means for each density and light combination (Table 4) clarified the interaction. Abalone raised at low densities grew much faster than abalone grown at high densities. Growth of abalone in the dark treatment was slightly greater than growth under fluorescent light. Abalone in sunlight grew slower than those in other light treatments, but the difference in growth was more pronounced at higher densities. Thus, light condition had a greater effect on growth as abalone density increased.

The 3-way interaction effect of time, light, and density was not significant (Table 3). Two-way interactions of light and density with time were significant, indicationg 
that growth was not constant during the experimental period. In both cases, differences were more pronounced as the abalone grew larger (see Part II: Figures 3,4 ).

The final treatment compared growth of abalone reared without disturbance for 6 months to those measured every 3 weeks (Table 5, Figure 3). The undisturbed abalone tended to grow larger than the abalone measured periodically. This difference in growth, however, was not significant $(\underline{P}=$ 0.1269 ; Table 6).

\section{DISCUSSION}

Abalone are nocturnal animals that restrict their activity to night time hours (Uki, 1981; Kikuchi and Uki, 1984). The increased growth of juveniles kept in the dark (Table 4) may be attributed to their nocturnal behavior. If abalone are reared in the dark, their feeding rate may be higher. Unfortunately, the results are not conclusive because factors interacted.

Growth rates observed for abalone under fluorescent light are slightly lower than those kept in the dark. The level of illumination in each these light treatments may explain the observed similarity in growth rates. Although containers in the fluorescent light treatment area appeared highly illuminated, the light available to abalone under 
this treatment exceeded total darkness by only $0.6 \mu \mathrm{E} \mathrm{s}^{-1} \mathrm{~m}^{-2}$. This difference is slight when compared to the much higher light intensity in the natural photoperiod treatment area $\left(122 \mu \mathrm{E} \mathrm{s}^{-1} \mathrm{~m}^{-2}\right)$.

The lower growth rates observed in the sunlight treatment group may indicate that feeding activity was inhibited by the presence of light at medium and high densities. It appears light intensity does not have a measurable effect, however, until density exceeds 10 abalone per container, or 189 individuals $/ \mathrm{m}^{2}$.

The presence of diatoms in the natural photoperiod group may also explain the interaction of light and density treatments. There was no diatom growth in the dark treatment containers and very little diatom growth was observed under fluorescent light. Diatom growth flourished in the containers exposed to sunlight, and it is likely that abalone in this group consumed diatoms as a supplement to their kelp diet. Diatoms may play a lesser role at higher densities, since available surface area for diatom growth would decrease with increasing abalone density. Consequently, differences between the sunlight treatment and the other 2 light treatments may have been more pronounced if it had been possible to control the effect of diatoms on abalone growth in the natural photoperiod group. 
Abalone maintained at low densities grew significantly better than those at higher densities under all light conditions (Table 4). In each light treatment, growth rate declined as the number of abalone increased. This difference is more pronounced between medium and high densities than between medium and low densities, suggesting that optimum rearing density may be 189-568 abalone $/ \mathrm{m}^{2}$. This range compares well to optimum densities reported for other abalone species of similar size. Chen (1984) found that $\underline{H}$. tuberculata grew best at $250 / \mathrm{m}^{2}$, and that growth was adversely affected when abalone were stocked at $750 / \mathrm{m}^{2}$. Likewise, Shibui (1972) reported a decrease in shell length when density of $\underline{H}$. discus hannai exceeded $200 / \mathrm{m}^{2}$.

One way to evaluate the significance of these findings to aquaculture is to determine how growout stage, the period of time between weaning and marketable size; is affected (Table 7). The market size for cultured red abalone is currently $50.8 \mathrm{~mm}-101.6 \mathrm{~mm}(2-4 \mathrm{in})$. Assuming that growth is nearly linear from 33 weeks to growout age, results of this experiment suggest that a juvenile abalone raised in the dark at low density will reach marketable size 1.2 years sooner than an abalone raised in the dark at high density (Table 7). Similarly, juveniles kept in darkness at high 
density will reach marketable size 0.9 years faster than those exposed to sunlight at high densities. Such improvements in growth may warrant modifying the growout area of an aquaculture facility to provide more favorable growing conditions. In contrast, rearing juvenile abalone under fluorescent light rather than total darkness would decrease growout time by only $0.1-0.2$ years. Implementing such a change may not be economically feasible. Ultimately, the practicality of altering density and light conditions to improve growth will depend upon the economic standing and long term goals of the aquaculture facility. The observation of decreased growth rates at higher densities indicates that abalone are either consuming less food or converting less food to growth as conditions become more crowded. A number of physiological and behavioral factors may account for this; however, information regarding these aspects of abalone biology is sparse or largely speculative. Some investigators have demonstrated increased aggression, sometimes manifested as cannibalism, in other molluscs (Rollo and Wellington, 1979). Cannibalism has been observed in abalone at high densities (Earl Ebert, pers. comm.), but was not observed in this study. Aggressive behavior may require more energy, leaving less energy for growth. Tattersfield (1982) found that in Trichia 
striolata, crowding caused a decline in feeding and an increase in locomotion. These behaviors may also translate into less energy for growth.

oxygen availability may decline as density increases, resulting in lower metabolic rates and reduced food conversion efficiency. Researchers have also reported a higher rate of mucus production in various molluses at high densities (Cameron and Carter, 1979; Tattersfield, 1982). Cameron and Carter (1979) have shown a considerable inhibition of growth in cepaea spp. due to the presence of mucus. Moreover, Peck et al. (1987) reported that mucus production in abalone requires a high expenditure of energy, and culley and sherman (1985) found that mucus production is increased when abalone are distressed or placed on rough substrates. Abalone stocked at high densities may produce more mucus in response to increased stress, or to aid in locomotion, since under crowded conditions they are forced to crawl over the rough shell surfaces of other abalone. If a greater portion of an abalone energy budget is allocated toward mucus production, it will be at the expense of other physiological functions such as growth.

A detrimental handling effect on growth was not observed in this experiment. Although growth rates of abalone measured periodically were below growth rates of 
undisturbed abalone (Table 5), the difference was not significant (Table 6). An effort was made to minimize trauma to abalone during measurement by keeping them out of the water as little as possible, and taking measurements quickly. This may account for the lack of a handing effect. Nevertheless, the observation that disturbed abalone grew even slightly worse than undisturbed abalone indicates that some stress was induced by periodic handling; juvenile abalone should thus be handled as infrequently as possible.

\section{LITERATURE CITED}

Cameron, R.A.D. and Carter, M.A., 1979. Intra- and interspecific effects of population density on growth and activity in some helicid land snails (Gastropoda: Pulmonata). J. Anim. Ecol., 48:237-246.

Chen, i., 1984. Recent innovations in cultivation of edible molluscs in Taiwan, with special reference to the small abalone Haliotis diversicolor and the hard clam Meretrix lusoria. Aquaculture, 39:11-27.

Cole, J.W.L. and Grizzle, J.E., 1966. Applications of multivariate analysis of variance to repeated measures experiments. Biometrics, $22: 810-828$.

Culley, M. and Sherman, K., 1985. The effect of substrate 
particle size on the production of mucus in Haliotis tuberculata $L$. and the importance of this in a culture system. Aquaculture, $47: 327-334$.

Ebert, E.E. and Houk, J.I., 1984. Elements and innovations in the cultivation of red abalone Haliotis rufescens. Aquaculture, 39:375-392.

Hadley, N.H. and Manzi, J.J., 1982. Some relationships affecting growth of seed of the hard clam Mercenaria mercenaria in raceways. Natl. Shellfish. Assoc. Ann. Meeting, 92 .

Hahn, K.0., 1989. Handbook of Culture of Abalone and Other Marine Gastropods. CRC Press, Inc., Florida, 348pp. Hooker, N. and Morse, D.E., 1984. Abalone: the emerging development of commercial cultivation in the United States. In: D.E. Morse, K. Chew, and R. Mann (Editors), Recent innovations in the cultivation of Pacific molluscs. Elsevier, New York, pp. 365-413.

Howorth, P.C., 1988. The Abalone Book. Naturegraph Publishers, Inc., Happy Camp, CA, 80pp.

Hurlbert, S.H., 1984. Pseudoreplication and the design of ecological field experiments. Ecol. Monogr., 54:187211.

Ino, T., 1952. Biological studies on the propagation of Japanese abalone (genus Haliotis). Bull. Tokai Reg. 
Fish. Res. Lab., 5:1-102.

Kan-no, H., 1975. Recent advances in abalone culture in

Japan. Proc. First Intl. Conf. Aqua. Nutr., 1:195-211.

Kikuchi, s. and Uki, N., 1984. Regulation of maturation and spawning of an abalone, Haliotis (Gastropoda) by external environmental factors. Aquaculture, 39:247.

Kline, T.C., 1982. The effect of population density on the growth of the butter clam Saxdomus gigantus. Natl. Shellfish. Assoc. Meeting, 112.

Koike, Y., Flassch, J. and Mazurier, J., 1979. Biological and ecological studies on the propagation of the ormer, Haliotis tuberculata Linnaeus. II. Influence of food and density on the growth of juveniles. La mer, 17:4352.

LaTour, S.A. and Miniard, P.W., 1983. The misuse of repeated measures analysis in marketing research. $J$. Marketing Res., 10:45-57.

Leighton, D.L., 1972. Laboratory observations on the early growth of the abalone, Haliotis sorenseni, and the effect of temperature on larval development and settling success. Fish. Bull., 70(2):373-381. Manzi, J.J., Hadley, N.H. and Maddox, M.B., 1986. Seed clam, Mercenaria mercenaria, culture in an experimental -scale upflow nursery system. Aquaculture, 54:301-311. 
Morse, D.E., 1984. Prospects for the California abalone resource: recent development of new technologies for aquaculture and cost-effective seeding for restoration and enhancement of commercial and recreational fisheries. In: S. Hanch (Editor), Ocean studies, Calif. Coastal Comm., San Francisco, 165.

olsen, S., 1982. Abalone and scallop culture in puget Sound. Abstracts, NSA West Coast section Meeting, Olympia, WA.

Peck, L.S., Culley, M.B. and Helm, M.M., 1987. A laboratory energy budget for the ormer Haliotis tuberculata L. J. Exp. Mar. Biol. Ecol., 106:103-123.

Rollo, C.D. and Wellington, W.G., 1979. Intra- and interspecific agonistic behaviour among terrestrial slugs (Pulmonata: Stylommatophora). Can. J. Zool., $57: 846-855$.

SÂs Institute Iñc., 1980. SASjSTAT User's Guide, release 6.03 edition. Cary, NC, 1028pp. Shibui, T., 1972. On the normal development of the eggs of Japanese abalone, Haliotis discus hannai Ino, and ecological and physiological studies of its larvae and youngs. Bull. Iwate Pref. Fish. Exp. Stat., 2:1-60. Tattersfield, P., 1982. Behavioural aspects of niche separation and population dynamics in terrestrial 
molluscs. Ph.D. Thesis, Univ. of Birmingham, England.

Uki, N., 1981. Feeding behavior of experimental populations of the abalone, Haliotis discus hannai. Bull. Tohoku Reg. Fish. Res. Lab., 43:53-58.

Underwood, A.J., 1981. Techniques of analysis of variance in experimental marine biology and ecology. Oceanogr. Mar. Biol. Ann. Rev., 19:513-605.

Winer, B.J., 1971. Statistical Principles in Experimental Design, 2nd Edition, McGraw-Hill Book Co., New York. Woon, G.I., 1983. Preliminary algal. preference studies and observations of conchs, strombus gigas L. and strombus costatus Gmelin. J. World Maricult. Soc., 14:162-163.

Zar, J.H., 1984. Biostatistical Analysis. Prentice-Hall Inc., Englewood Cliffs, NJ., 717pp. 
Table 1. Growth of juvenile abalone exposed to 1 of the following 3 light conditions: sunlight (natural photoperiod) (S), fluorescent light (F), or $24 \mathrm{~h}$ darkness (D). Measurements represent mean shell lengths (mm) from 9 containers per light treatment with 10,30 , or 75 abalone per container ( 3 containers/density). Standard deviations are reported in parentheses following the means. Abalone were 33 weeks of age initially, and 57 weeks old at the end of the experiment. $(\underline{N}=9)$.

\begin{tabular}{ccccc}
\hline $\begin{array}{c}\text { Light } \\
\text { Condition }\end{array}$ & $\begin{array}{c}\text { Initial Mean } \\
\text { Length }\end{array}$ & $\begin{array}{c}\text { Final Mean } \\
\text { Length }\end{array}$ & Mean Growth \\
\hline S & $11.26(2.114)$ & $18.59(4.351)$ & 7.33 \\
F & $11.11(1.828)$ & $20.06(3.815)$ & 8.95 \\
D & $11.30(2.001)$ & $20.25(4.172)$ & 8.95 \\
\hline
\end{tabular}


Table 2. Growth of juvenile abalone maintained at 1 of the following 3 rearing densities: high $(H)$ (75/container; $1420 / \mathrm{m}^{2}$ ), medium (M) (30/container; $\left.568 / \mathrm{m}^{2}\right)$, and $10 \mathrm{w}$ (L) (10/container; $\left.189 / \mathrm{m}^{2}\right)$. Measurements represent mean shell lengths (mm) from 9 containers per density under 3 different light conditions ( 3 containers/light condition). Standard deviations are reported in parentheses following the means. Abalone were 33 weeks of age initially, and 57 weeks old at the end of the experiment. $(\underline{\mathbb{N}}=9)$.

\begin{tabular}{ccccc}
\hline $\begin{array}{l}\text { Rearing } \\
\text { Density }\end{array}$ & $\begin{array}{c}\text { Initial Mean } \\
\text { Length }\end{array}$ & $\begin{array}{c}\text { Final Mean } \\
\text { Length }\end{array}$ & Mean Growth \\
\hline H & $11.03(1.952)$ & $18.13(3.874)$ & 7.10 \\
M & $11.75(2.051)$ & $21.76(3.764)$ & 10.01 \\
L & $11.15(1.756)$ & $22.74(2.851)$ & 11.59 \\
\hline
\end{tabular}


Table 3. Analysis of variance test comparing differences in abalone growth among various light conditions (sunlight, fluorescent light, $24 \mathrm{~h}$ darkness) and rearing densities $\left(189 / \mathrm{m}^{2}, 568 / \mathrm{m}^{2}, 1420 / \mathrm{m}^{2}\right)$.

\begin{tabular}{lllllll}
\hline Source & DF & SS & MS & F & P \\
\hline
\end{tabular}

Between-Subjects Effects

$\begin{array}{lrrrrc}\text { Light } & 2 & 10.95 & 5.48 & 2.40 & 0.1209 \\ \text { Density } & 2 & 246.99 & 123.50 & 54.08 & 0.0001 \\ \text { Light X Density } & 4 & 32.29 & 8.07 & 3.54 & 0.0283 \\ \text { Error } & 17 & 38.82 & 2.28 & -- & -\end{array}$

Within-Subjects Effects

\begin{tabular}{lrrrrc} 
Time & 8 & 2484.43 & 310.55 & 3413.36 & 0.0001 \\
Time X Light & 16 & 16.70 & 1.04 & 11.47 & 0.0001 \\
Time X Density & 16 & 79.12 & 4.94 & 54.35 & 0.0001 \\
T X L X D & 32 & 2.87 & 0.09 & 0.98 & 0.4987 \\
Error (Time) & 136 & 12.37 & 0.09 & -- & -- \\
\hline
\end{tabular}


Table 4. Mean growth in shell length (mm) of juvenile abalone raised under various light and density conditions for 6 months. Average growth per month is given in parentheses. $(\underline{N}=3)$.

\begin{tabular}{|c|c|c|c|}
\hline \multirow[b]{2}{*}{ Light Level } & \multicolumn{3}{|c|}{ Rearing Density } \\
\hline & $\mathrm{H}$ & $\mathbf{M}$ & $\mathbf{L}$ \\
\hline $\begin{array}{l}\text { S } \\
\text { F } \\
\text { D }\end{array}$ & $\begin{array}{ll}6.05 & (1.01) \\
7.48 & (1.25) \\
7.81 & (1.30)\end{array}$ & $\begin{array}{rr}9.05 & (1.51) \\
10.32 & (1.72) \\
10.70 & (1.78)\end{array}$ & $\begin{array}{ll}11.29 & (1.88) \\
11.72 & (1.88) \\
12.22 & (2.04)\end{array}$ \\
\hline
\end{tabular}


Table 5. Growth of juvenile abalone subjected to 1 of 2 handling treatments for 6 months: no handling (NH) or periodic handling ( $\mathrm{PH})$. Abalone in the $\mathrm{NH}$ group were measured only at the beginning and end of the experiment, while those in the $\mathrm{PH}$ group were measured every 3 weeks. Handling treatments were applied to abalone at 3 densities: high $(\mathrm{H})\left(75 /\right.$ container; $\left.1420 / \mathrm{m}^{2}\right)$, medium $(\mathrm{M})(30 /$ container; $\left.568 / \mathrm{m}^{2}\right)$, and low (L) $\left(10 /\right.$ container; $\left.189 / \mathrm{m}^{2}\right)$. Measurements represent mean shell lengths $(\mathrm{mm})$ from 3 containers per treatment per density, for a total of 9 containers per handling treatment. Abalone were 33 weeks of age initially, and 57 weeks old at the end of the experiment.

\begin{tabular}{cccccr}
\hline $\begin{array}{l}\text { Handing } \\
\text { Treatment }\end{array}$ & Density & N & $\begin{array}{c}\text { Initial Mean } \\
\text { Length }\end{array}$ & $\begin{array}{c}\text { Final Mean } \\
\text { Length }\end{array}$ & $\begin{array}{c}\text { Mean } \\
\text { Growth }\end{array}$ \\
\hline & & & $11.15(1.661)$ & $19.87(3.336)$ & 8.72 \\
NH & H & 3 & $10.96(1.831)$ & $22.47(3.455)$ & 11.51 \\
NH & M & 3 & 10.972 \\
NH & L & 3 & $10.70(2.035)$ & $24.47(4.834)$ & 13.77 \\
PH & H & 3 & $11.34(2.037)$ & $19.15(4.004)$ & 7.81 \\
PH & M & 3 & $11.48(1.994)$ & $22.18(3.833)$ & 10.70 \\
PH & L & 3 & $10.52(1.596)$ & $22.74(3.195)$ & 12.22 \\
\hline
\end{tabular}


Table 6. Analysis of variance test comparing differences in abalone growth between 2 handling methods: no handling and handling every 3 weeks.

\begin{tabular}{lrrrrr}
\hline Source & DF & SS & MS & F & P \\
\hline Handling Method & 1 & 4.88 & 4.88 & 2.69 & 0.1269 \\
Density & 2 & 5241.07 & 2620.53 & 1445.64 & 0.0001 \\
HM x Density & 2 & 2.41 & 1.21 & 0.67 & 0.5319 \\
Error & 12 & 21.75 & 1.81 & -- & -- \\
\hline
\end{tabular}


Table 7. Estimates of time (years) required to reach market size in juvenile abalone, based on growth rates of animals raised under aifferent light and density levels for 6 months. The first letter in the treatment corresponds to 1 of 3 light conditions - S (natural photoperiod), $F$ (fluorescent light), D (24 h darkness); the second letter represents high $(\mathrm{H})$, medium $(\mathrm{M})$, or low (L) density. ( $N=$ 3).

\begin{tabular}{cccc}
\hline Treatment & $50.8 \mathrm{~mm}$ & $76.2 \mathrm{~mm}$ & $101.6 \mathrm{~mm}$ \\
\hline SH & 4.2 & 6.3 & 8.4 \\
SM & 2.8 & 4.2 & 5.6 \\
SL & 2.3 & 3.4 & 4.5 \\
FH & 3.4 & 5.1 & 6.8 \\
FM & 2.5 & 3.7 & 4.9 \\
FL & 2.3 & 3.4 & 4.5 \\
DH & 3.3 & 4.9 & 6.5 \\
DM & 2.4 & 3.6 & 4.8 \\
DL & 2.1 & 3.1 & 4.2 \\
\hline
\end{tabular}


Figure 1. Growth of juvenile abalone exposed to 1 of 3 light conditions for 6 months: fluorescent light (circles), $24 \mathrm{~h}$ darkness (squares), or sunlight (triangles). 


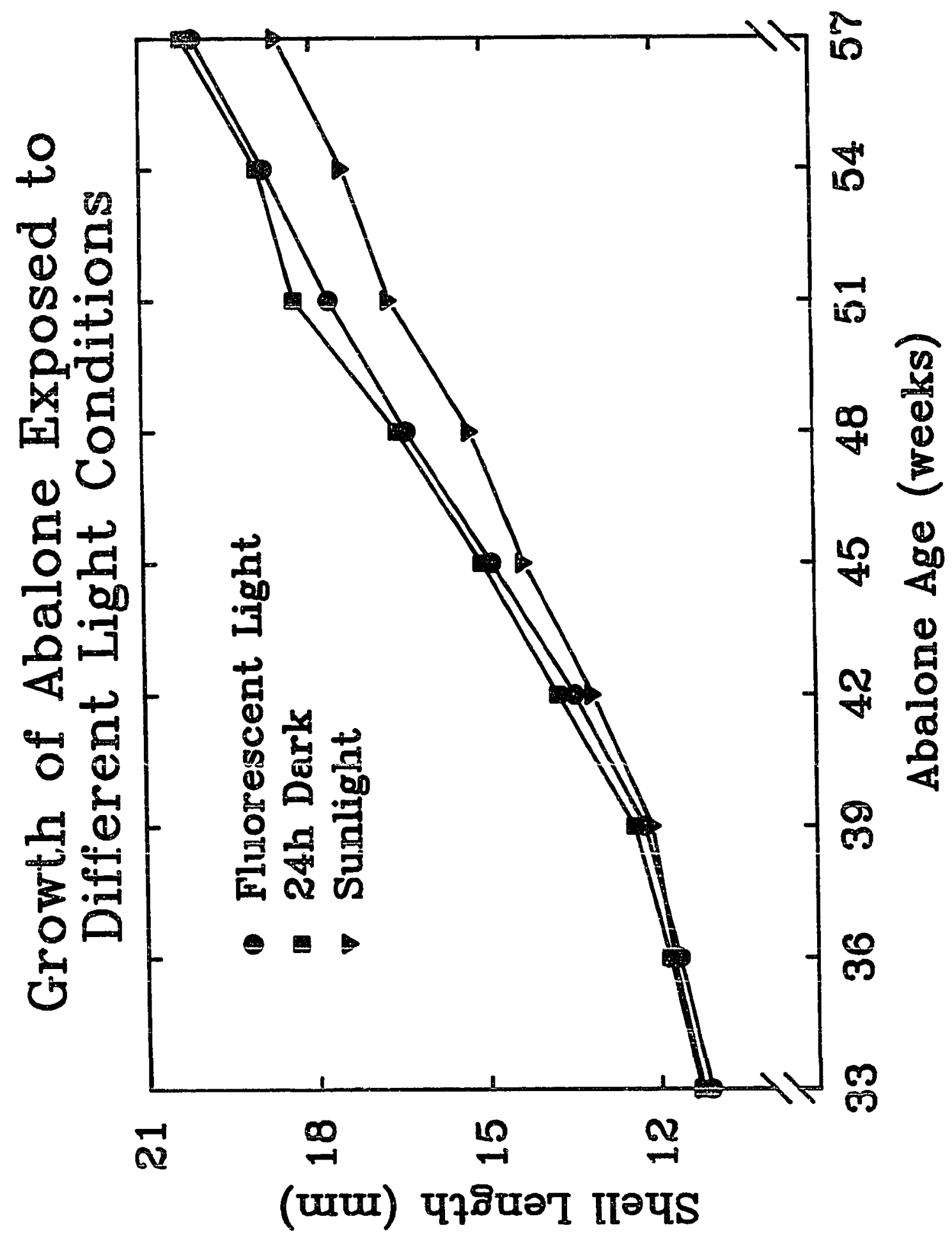


Figure 2. Growth of juvenile abalone stocked at 1 of 3 density levels for 6 months: high $\left(1420 / \mathrm{m}^{2}\right.$; circles), medium (568 $\mathrm{m}^{2}$; triangles), or low $\left(189 / \mathrm{m}^{2} ;\right.$ squares $)$. 


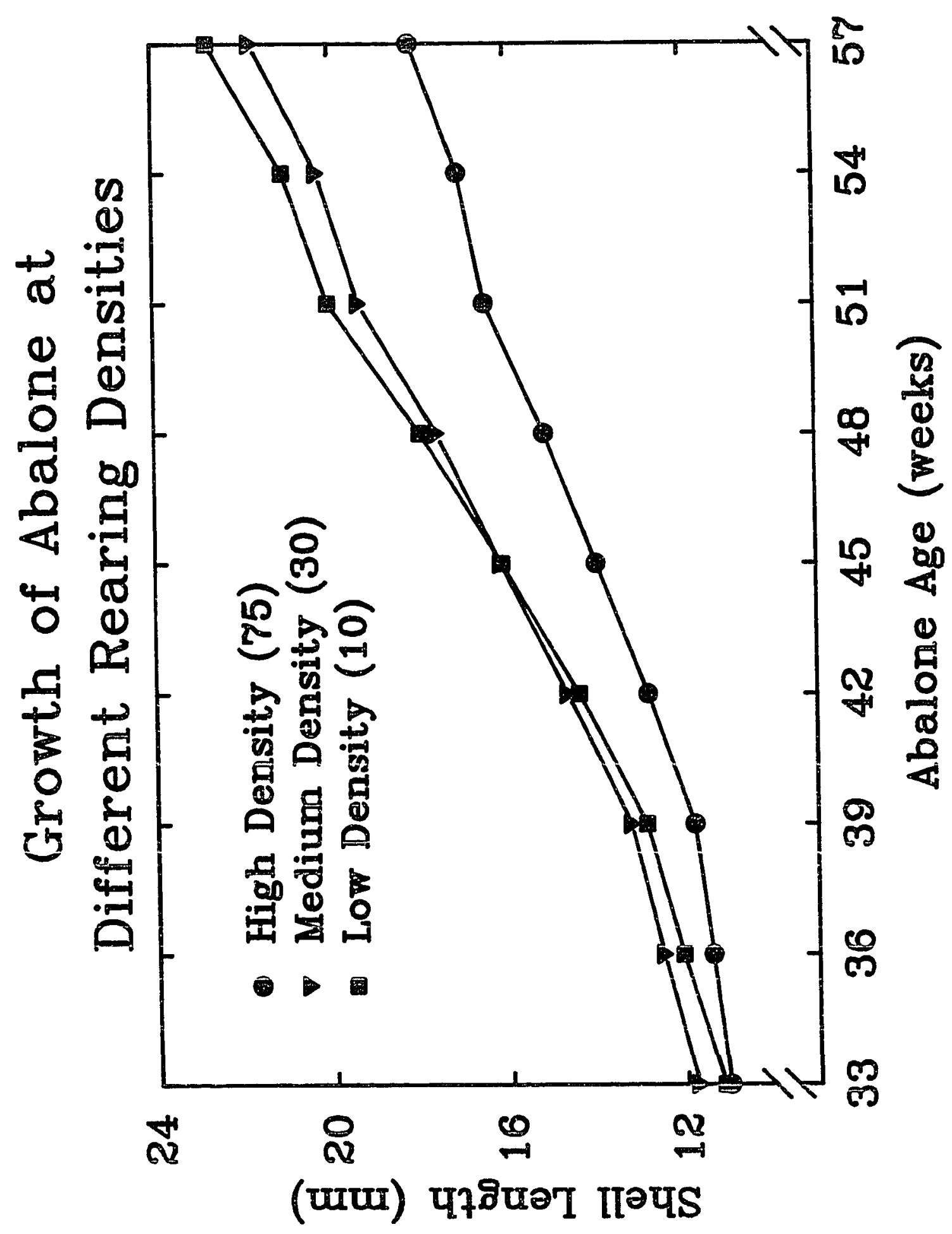


Figure 3. Growth of juvenile abalone subjected to 1 of 2 handling treatments: no handling ( $\mathrm{NH}$ ) or periodic handling ( $\mathrm{PH}$; measured every 3 weeks). 


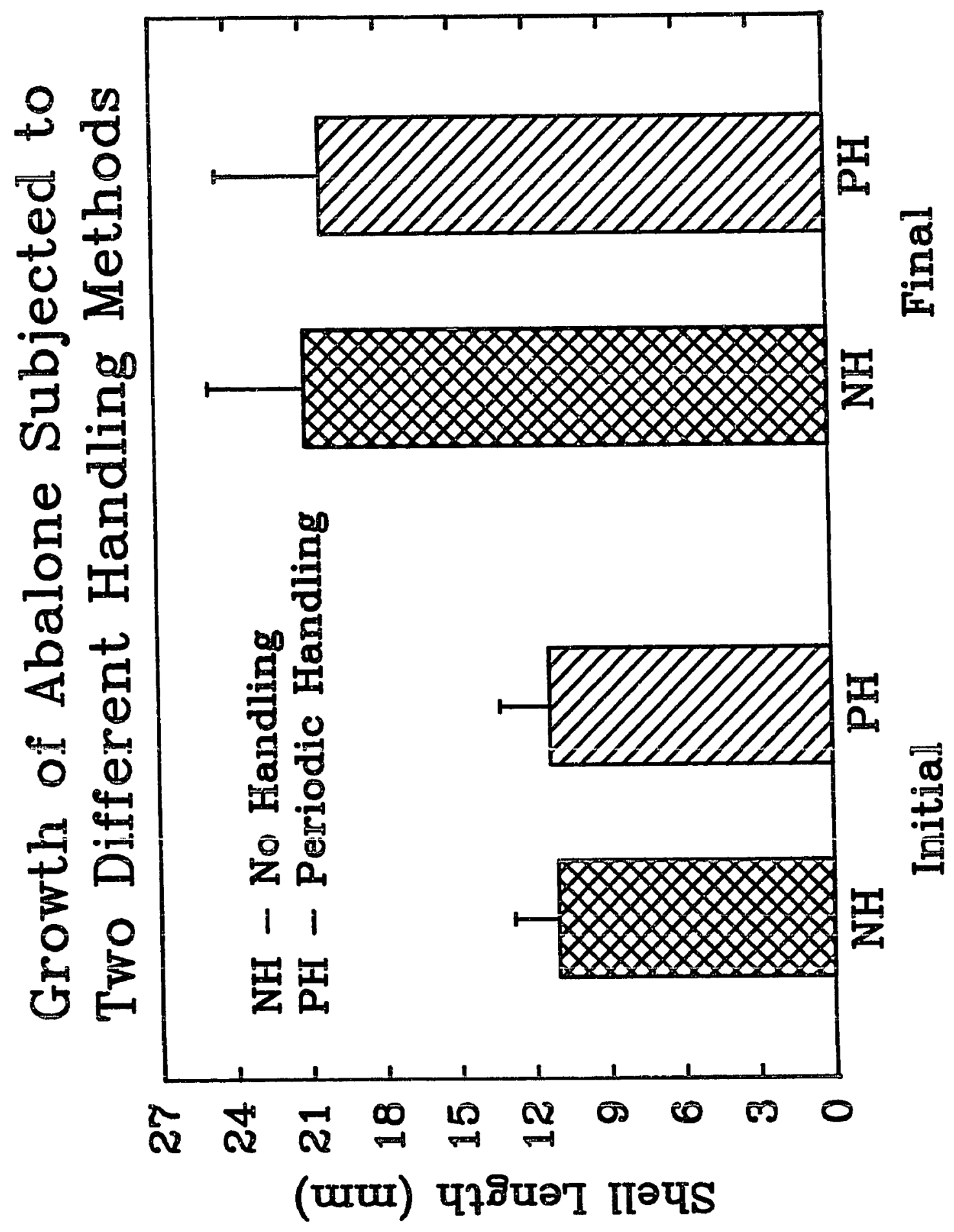


PART II

Growth Models and Food Conversion of Juvenile Red Abalone Cultured under Various Light and Density Conditions 


\section{INTRODUCTION}

Interest in the artificial propagation of the red abalone (Haliotis rufescens) has increased in recent years (Ebert and Houk, 1984). Depletion of wild populations has created a greater market for commercially produced animals. In addition, development of improved cultivation techniques has made commercial production of the red abalone more economically viable (Hooker and Morse, 1984).

Maximizing juvenile abalone growth is a critical component of successful commercial production. Many mathematical models have been used to describe growth (Clow and Urquhart, 1974; Ricker, 1975). Growth equations can be used to predict "age to length" or time necessary to reach a certain size. Hatchery applications include projections of age for weaning or growout, or age at marketable size.

A variety of factors are known to influence growth in young abalone (Leighton, 1972; Chen, 1984), including rearing density (Shibui, 1972, Koike, 1979) and light (Shibui, 1972; Uki, 1981; Olsen, 1982). The primary goal of this study was to develop a model to describe juvenile red abalone growth under a variety of conditions for broad application to commercial production.

Food use indices are used to predict intake, assimilation, and production efficiencies. A FC ratio is 
the amount of food needed to produce a unit of animal weight gain (Parker, 1987) and is used to calculate feed costs. FR is a measure of the amount of food an animal consumes relative to its body weight (Ebert and Houk, 1984) and provides another way of estimating food requirements. Feeding rate (FR) and feed conversion (FC) were also examined to describe relationships between these variables and juvenile abalone growth.

\section{MATERIALS AND METHODS}

\section{Location and Experimental Conditions}

Research was conducted at Granite Canyon Marine Resources Laboratory, a California Department of Fish and Game (CDFG) facility located south of Carmel, California from November 1988 to April 1989. Thirty-three week old juvenile red abalone spawned from laboratory broodstock were usea as experimental animals. Abalone were kept in cylindrical plastic containers $(14.0 \mathrm{~cm}$ inside diameter $\mathrm{x}$ $12.0 \mathrm{~cm}$ height) in a rectangular water table $(2.2 \mathrm{~m} \times 0.9 \mathrm{~m}$ $x 0.3 \mathrm{~m})$. Filtered $(1.0 \mu \mathrm{M})$ seawater was distributed to containers with a PVC pipe $(2.5 \mathrm{~cm})$ manifold. Water $\left(15^{\circ} \mathrm{C} \pm 0.5^{\circ} \mathrm{C}\right)$ was supplied at $1.5 \pm 0.51 / \mathrm{min}$, and containers were aerated with air stones. Abalone were stocked at 3 densities: low $\left(189 / \mathrm{m}^{2}\right)$, 
medium $\left(568 / \mathrm{m}^{2}\right)$, and high $\left(1420 / \mathrm{m}^{2}\right)$ or 10,30 , and 75

abalone. Light treatments included: natural--sunlight

filtered through fiberglass panels; artificial--fluorescent

light following natural photoperiod; and no light--24 h

darkness. Black plastic partitions were used to separate

light treatments.

The experimental unit was defined as a single container subjected to a treatment combination. Abalone were treated as repeated measures (Hurlbert, 1984), and growth measurements were averaged for each container. Treatments (replicated, 3 times) were randomly assigned to containers. Densities were randomly positioned in each light section.

\section{Growth Measurements}

Growth measurements from all abalone (shell length, shell width, wet body weight) were taken every 3 weeks. Length and width were measured with a vernier calipers to $0.05 \mathrm{~mm}$. Weight was measured with a Mettler ${ }^{R}$ digital balance to $0.01 \mathrm{~g}$.

\section{Correlation of Growth variables}

Pearson correlation analysis (SAS, 1988) was used to determine relationships among growth parameters (length, width and weight). Samples from each 3-week measurement 
period were not independent, precluding use of correlation analysis across sample periods (Underwood, 1981). Therefore, correlation was performed only on observations from the last measurement period. A linear regression was used to relate length and weight. Length measurements were used for analyses because shell length is usually used to determine time for weaning, growout, and harvest.

\section{Growth Models}

Three mathematical growth models were fit to the length data: (1) logistic (Clow and Urquhart, 1974),

$$
L=\operatorname{Lmin} \frac{1+b}{1+b e^{-k t}}
$$

where $L$ is shell length (mm) at time $t$; Lmin is the shell length at the beginning of the experiment; $e$ is the base of the natural system of logarithms; and $k$ and are $b$ positive growth constants; (2) Gompertz (Clow and Urquhart, 1974),

$$
L=\operatorname{Imax} e^{-c e^{-k t}}
$$

where Imax is the asymptotic, or maximum shell length; and $c$ and $k$ are positive growth constants; and (3) von Bertalanffy (Clow and Urquhart, 1974),

$$
L=I \max \left(1-b e^{-k t}\right)^{3}
$$

where Lmax is the maximum shell length, and $b$ and $k$ are positive growth constants. In the equations, $t$ is equal to the age of the abalone in weeks minus 33 . 
Iterative least squares nonlinear regressions were used to fit each model to the data and estimate model parameters (Marquardt, 1963; SAS, 1988). Imax was defined as "the length that an average animal would achieve if it continued to live and grow indefinitely" (Ricker, 1975). Imax was set at $300 \mathrm{~mm}$ based on reports of the maximum length recorded for red abalone in the wild (Hooker and Morse, 1984; Howorth, 1988). The model with the smallest residual error was selected as the model that best fit the data (Fabens, 1965)

\section{Food Consumption}

Abalone were maintained on an ad libitum diet of kelp (Macrocystis spp). Containers were cleaned, remaining food was collected and weighed, and fresh kelp was added each week. Estimates of feed conversion (FC) were calculated following Parker (1987),

$$
\text { FC }=\frac{\text { Weight of feed ingested }(g)}{\text { Weight gain by abalone ( }(g)}
$$

Feeding rate (Ebert and Houk, 1984) was determined by the equation,

$$
\text { Feeding Rate }(\%)=\frac{F_{1}}{t} \frac{-F_{2}}{x} \times 100
$$

where $F_{1}=$ initial food weight, $F_{2}=$ final food weight, $t=$ number of days, and $w=$ mean abalone weight. Analysis of 
variance (ANOVA) procedures were used to test significance of FC and FR among treatments. ANOVA tests were deemed significant at $\underline{\mathrm{P}} \leq 0.05$.

\section{RESULTS}

\section{correlation of variables}

Growth variables were highly correlated (Table 1). The variables length and width were most closely related, with a Pearson correlation coefficient of 0.9872 . The linear regression relating length and weight was $\left(\underline{r}^{2}=0.9814, \underline{N}=\right.$ $8, \underline{\mathrm{P}}=0.0001)$

$$
\text { Weight }=-1.0338+0.1049(\text { length })
$$

\section{Growth of Abalone}

Abalone averaged $11.23 \mathrm{~mm}$ (range: $7.25-18.00 \mathrm{~mm}$ ) in length and $0.19 \mathrm{~g}$ (range: $0.05-0.70 \mathrm{~g}$ ) in weight when the experiment began. They grew an average of $8.37 \mathrm{~mm}$ in length and $0.90 \mathrm{~g}$ in weight over the 6-month study (Table 2; Figure 1).

\section{Growth Models}

All models fit the data well with similar residuals (Figure 1, Table 3). An ANOVA test of residual values for all treatment combinations revealed that Gompertz and von 
Bertalanffy models fit the data significantly better than the logistic model (Table 3). Although there was no significant difference between Gompertz and von Bertalanffy models, the von Bertalanffy model had the smallest mean residual error (Table 3), and was selected as the model that best fit the growth data (Figure 2 ).

The models fit the data equally well for all treatments $(\underline{P}=0.2670, \underline{N}=6, \underline{F}=1.27)$. Differences were observed among treatments with regard to their effect on growth but are presented elsewhere (see Part I). Growth curves were generated for all treatments from length observations using the von Bertalanffy growth equation (Figures 3-4). All treatments resulted in a similar pattern of growth. Estimates of von Bertalanffy growth parameters $b$ and $k$ were calculated (Table 4). Values for b ranged from 0.6661 0.6752 while $\mathrm{k}$ rangea from $0.00446-0.00653$.

\section{Food Indices}

Feeding rate varied from 3.3-10.9\% per day, and feed conversion ranged from 3.6-8.9 (Table 5). No obvious relationship between FC, FR, and abalone age could be discerned. ANOVA tests revealed a significant difference among treatments for FR (light: $\underline{\mathrm{P}}=0.0001, \underline{\mathrm{F}}=21.35, \underline{\mathrm{N}}=$ 27 ; density: $\underline{\mathrm{P}}=0.0001, \underline{\mathrm{F}}=23.07, \underline{\mathrm{N}}=27$ ) and FC (1ight: $\underline{\mathrm{P}}$ 
$=0.0001, \underline{E}=10.51, \underline{N}=27)$. All treatment interactions were also significant, however, resulting in confounding factors which mask true treatment effects.

\section{DISCUSSION}

\section{Growth Models}

Juvenile abalone growth in this study closely matches the shape of the decaying exponential von Bertalanffy curve and S-shaped Gompertz curve. Gompertz and von Bertalanffy models fit the data similarly, and may be equally appropriate for describing observed growth data (Ricker, 1975). The Gompertz model, however, is most often used to describe "weight at age" relationships (Ricker, 1975). The upper portion of the S-shaped Gompertz curve is similar in shape to the von Bertalanffy curve. Only the portion of the curve beyond the inflection point usually fits the data when applied to length data (Ricker, 1975).

The vor Bertalanffy model has been shown to characterize growth for many aquatic animals (Beverton and Holt, 1957; Sainsbury, 1982; Shepherd and Hearn, 1983; Tutschulte and connell, 1988). It is probably the better choice to describe growth of juvenile abalone, because growth is most often expressed in terms of length. The von Bertalanffy growth equation does not have an 
inflection point demarcating maximum growth rate.

Therefore, the Gompertz curve should be applied in cases where an inflection point is indicated. An inflection point may be useful in determining age at which abalone should be harvested for market since growth rate arops off beyond the inflection point on the Gompertz curve.

Application of the second derivative of the Gompertz equation to these data indicates a peak growth rate at 2.7 years of age. Caution must be exercised, however, in using a growth model to make predictions beyond the range of the data. This estimate is only valid if growth is asymptotic and Imax is estimated correctly. "Age to length" estimates beyond the size range examined in this study may not be accurate since the pattern of abalone growth varies with time (Leighton, 1972; Ebert and Houk, 1984).

Tegner et al. (1989) use an Lmax value of $201 \mathrm{~mm}$ for red abalone. However, this estimate is based on the maximum mean size for a wild population subject to predation and exploitation. Their maximum value is just above the minimum allowable commercial harvest size of $197 \mathrm{~mm}$. In this study, Imax was estimated to be the maximum recorded size of red abalone (Hooker and Morse, 1984; Howorth, 1988) similar to Tutschulte and Connell (1988).

The von Bertalanffy growth equation may be applied to 
these data to predict the age at which transfer for weaning from diatoms (5-10 mm; Ebert and Houk, 1984) or growout (12 mm; Ebert and Houk, 1984) should occur since these sizes are within the range of lengths observed in this experiment. This model predicts a growout age of 38 weeks.

Ideally, growth models should be constructed from data gathered during the entire commercial life cycle of the abalone. This information could be applied by hatchery managers who wish to make "age to length" projections for stages of abalone growth.

\section{Food Indices}

Although no distinct pattern emerged relating FR or FC to individual treatments, these results are not unusual as abalone are known to be erratic feeders, sensitive to a number of environmental and physiological influences (Shibui, 1972; Koike, 1979; Uki, 1981). In this experiment, FR values indicate that the abalone consumed between 3.310.9\% per day of their body weight in kelp. FC ratios indicate that $3.6-8.9 \mathrm{~g}$ per day of kelp are required to produce a $1 \mathrm{~g}$ increase in abalone weight.

Food use indices are based on weight of the animal. However, if size in length is known, FR and FC values can be related to abalone length by using the regression equation 
developed in this study for converting length to weight. FC and FR may be useful in providing an estimate of how much kelp juvenile abalone 10-30 mm in size will consume and convert to weight gain. For example, using the regression equation, $20 \mathrm{~mm}$ abalone average $1.06 \mathrm{~g}$ in weight. Table 5 indicates that abalone in the $10-30 \mathrm{~mm}$ size range (33-57 weeks of age) consume an average of $5.8 \%$ of their body weight, or $0.06 \mathrm{~g}$ of kelp per abalone per day. If there are $100,00020 \mathrm{~mm}$ abalone in an aquaculture facility, they will consume approximately $6000 \mathrm{~g}$ of kelp per day or $42 \mathrm{~kg}$ of kelp per week. Since the average FC for abalone in this size range is 5.4 (Table 5), $42 \mathrm{~kg}$ of kelp per week will result in $7.7 \mathrm{~kg}$ of total weight gain or $0.078 \mathrm{~g}$ of increased weight per abalone per week.

\section{IITERATURE CITED}

Beverton, R.H. and Holt, S.J., 1957. On the dynamics of exploited fish populations. Great Brit. Min. Agr. Fish., Fish. Invest., Ser. 2, 19:1-533.

Chen, H., 1984. Recent innovations in cultivation of edible molluscs in Taiwan, with special reference to the smali abalone Haliotis diversicolor and the hard clam Mexetrix lusoria. Aquaculture, 39:11-27.

Clow, D.J. and Urquhart, N.S., 1974. Mathematics in 
Biology: Calculus and Related Topics. W. W. Horton \& Co., Inc., New York, 727pp.

Ebert, E.E. and Houk, J.L., 1984. Elements and innovations in the cultivation of red abalone Haliotis rufescens. Aquaculture, 39:375-392.

Fabens, A.J., 1965. Properties and fitting of the von Bertalanffy growth curve. Growth, 29:265-289. Hooker, N. and Morse, D.E., 1984. Abalone: the emerging development of commercial cultivation in the United States. In: D.E. Morse, K. Chew, and R. Mann (Editors), Recent innovations in the cultivation of Pacific molluscs. Elsevier, New York, pp. 365-413. Howorth, P.C., 1988. The Abalone Book. Naturegraph Publishers, Inc., Happy Camp, California, 80pp. Huner, J.V. and Dupree, H.K., 1984. Methods and economics of channel catfish production, and techniques for the culture of flathead catfish and other catfishes. In: H.K. Dupree and J.V. Huner (Editors), Third report to the fish farmers: the status of warmwater fish farming and progress in fish farming research. U.S. Fish and wildlife Service, Washington, D.C., pp. 44-82. Hurlbert, S.H., 1984. Pseudoreplication and the design of ecological field experiments. Ecol. Monogr., 54:187211. 
Koike, Y., Flassch, J. and Mazurier, J., 1979. Biological and ecological studies on the propagation of the ormer, Haliotis tuberculata Linnaeus. II. Influence of food and density on the growth of juveniles. La mer, 17:4352 .

Leighton, D.I., 1972. Laboratory observations on the early growth of the abalone, Haliotis sorenseni, and the effect of temperature on larval development and settling success. Fish. Bull., 70(2):373-381.

Marquardt, D.W., 1963. An algorithm for least-squares estimation of nonlinear parameters. J. Soc. Indust. Appl. Math., 11:431-441.

Olsen, S., 1982. Abalone and scallop culture in Puget sound. In: Abstracts, NSA West coast section Meeting, Olympia, WA.

Paloheimo, J.E. and Dickie, L.M., 1966. Food and growth of Iishes. III. Reiation among food, wody size, and growth efficiency. J Fish Res. Board of Canada, 23:1209-1248. Parker, N.C., 1987. Feed conversion indices: controversy or convention? Prog. Fish Cult., 49:161-166.

Ricker, W.E., 1975. Computation and interpretation of biological statistics of fish populations. Fish. Res. Bd. Can. Bull., 91, 382pp.

SAS Institute Inc., 1988. SAS/STAT User's Guide, release 
6.03 edition. SAS Institute Inc., Cary, N.C., 1028pp. Sainsbury, K.J., 1982. Population dynamics and fishery management of the paua, Haliotis iris $I$. Population structure, growth, reproduction and mortality. N.Z.J. Mar. Freshwater Res., 16: 147-161.

Shepherd, S.A. and Hearn, W.S., 1983. Studies on southern Australian abalone (genus Haliotis). IV. Growth of $\mathrm{H}$. laevigata and H. ruber. Austr. J. Mar. Freshwater Res., $34: 461-475$.

Shibui, T., 1972. On the normal development of the eggs of Japanese abalone, Haliotis discus hannai Ino, and ecological and physiological studies of its larvae and youngs. Bull. Iwate Pref. Fish. Exp. Stat., 2:1-60.

Smith, R.R. and Rumsey, G.I., 1977. Nutrient utilization by fish. In: P.V. Fonnesbeck, I.E. Harris, and L.C. Kearl (Editors), Proceedings of the first international symposium on feed composition, animal nutrient requirements and computerization of diets. Utah state University, Logan, pp. 320-326.

Tutschulte, T. C. and Connell, J.H., 1988. Growth of 3 species of abalones (Haliotis) in southern California. The Veliger, 31: 204-213.

Uki, N., 1981. Feeding behavior of experimental populations of the abalone, Haliotis discus hannai. Bull. Tohoku 
Reg. Fish. Res. Lab., 43:53-58.

Underwood, A.J., 1981. Techniques of analysis of variance in experimental marine biology and ecology. oceanogr.

Mar. Biol. Ann. Rev., 19:513-605. 
Table 1. Correlation of growth variables measured for juvenile red abalone at 57 weeks of age. Values for the Pearson correlation coefficient, $\underline{r}$, are presented relating iength, width and weight. $(\underline{N}=957)$.

\begin{tabular}{lccc}
\hline Variable & Length & Width & Weight \\
\hline Length & 1 & --- & -- \\
Wiath & 0.9872 & 1 & 1 \\
Weight & 0.9533 & 0.9529 & \\
\hline
\end{tabular}


Table 2. Mean growth of juvenile red abalone over a 6-month period. $\mathrm{N}$ is the number of containers represented, with 10-75 abalone per container. One container of abalone was lost at week 51 due to cessation of water flow to that container.

\begin{tabular}{llccc}
\hline $\begin{array}{c}\text { Age } \\
\text { (weeks) }\end{array}$ & N & $\begin{array}{c}\text { Length } \\
(\mathrm{mm})\end{array}$ & $\begin{array}{c}\text { Width } \\
(\mathrm{mm})\end{array}$ & $\begin{array}{c}\text { Weight } \\
(\mathrm{g})\end{array}$ \\
\hline 33 & 27 & 11.23 & 7.55 & 0.19 \\
36 & 27 & 11.74 & 7.88 & 0.22 \\
39 & 27 & 12.26 & 8.18 & 0.27 \\
42 & 27 & 13.45 & 8.98 & 0.35 \\
45 & 27 & 14.76 & 9.87 & 0.46 \\
48 & 27 & 16.04 & 10.68 & 0.59 \\
51 & 27 & 17.54 & 11.65 & 0.78 \\
54 & 26 & 18.37 & 12.15 & 0.91 \\
57 & 26 & 19.60 & 12.91 & 1.09 \\
Mean & & & & 0.90 \\
Increase & & 8.37 & 5.36 & \\
\hline
\end{tabular}


Table 3. Comparison of growth models applied to juvenile red abalone growth data collected every 3 weeks over a 6month period. Abalone were 33 weeks of age and averaged $11.23 \mathrm{~mm}$ in length at the beginning of the experiment. Values represent the residual errors of each model after applying nonlinear regression procedures.

\begin{tabular}{lcccc}
\hline & \multicolumn{3}{c}{ Residual } \\
\cline { 2 - 4 } Model & Total & Mean & SE \\
\hline Logistic & 14.21 & 0.30 & 0.0320 & $\mathrm{~A}^{1}$ \\
Gompertz & 9.70 & 0.20 & 0.0202 & $\mathrm{~B}$ \\
von Bertalanffy & 9.27 & 0.19 & 0.0188 & $\mathrm{~B}$ \\
\hline
\end{tabular}

${ }^{1}$ Significantly different from the other 2 models. 
Table 4. Parameters calculated for the von Bertalanffy model for juvenile red abalone grown under various light and density conditions for a period of 6 months $(\underline{N}=9)$. B and $\mathrm{k}$ are positive growth constants, and ASE is the average standard error.

Model Parameters

Treatment

$\mathrm{b}$

ASE

$\mathrm{k}$ ASE

Light

$\begin{array}{lllll}24 \mathrm{~h} \mathrm{Dark} & 0.6724 & 0.0034 & 0.00536 & 0.00021 \\ \text { Fluorescent } & 0.6745 & 0.0024 & 0.00537 & 0.00015 \\ \text { Sunlight } & 0.6724 & 0.0022 & 0.00446 & 0.00014\end{array}$

Density

$\begin{array}{lllll}\text { Low } & 0.6728 & 0.0035 & 0.00653 & 0.00021 \\ \text { Medium } & 0.6661 & 0.0025 & 0.00563 & 0.00016 \\ \text { High } & 0.6752 & 0.0028 & 0.00448 & 0.00017\end{array}$


Table 5. Daily mean feeding rate (FR: Ebert and Houk, 1984) and feed conversion (FC: Parker, 1987) values calculated for juvenile red abalone reared under a variety of light and density conditions for 6 months (S.D. = standard deviation).

\begin{tabular}{|c|c|c|c|c|c|}
\hline \multirow[b]{2}{*}{$\begin{array}{c}\text { Age } \\
\text { (weeks) }\end{array}$} & \multirow[b]{2}{*}{$\mathrm{N}$} & \multicolumn{2}{|c|}{$\operatorname{FR}\left(\frac{\circ}{\sigma}\right)$} & \multicolumn{2}{|c|}{ FC } \\
\hline & & $\overline{\text { Mean }}$ & $\overline{\text { S.D. }}$ & $\overline{\text { Mean }}$ & S.D. \\
\hline $\begin{array}{l}36 \\
39 \\
42 \\
45 \\
48 \\
51 \\
54 \\
57\end{array}$ & $\begin{array}{l}27 \\
27 \\
27 \\
27 \\
27 \\
27 \\
26 \\
26\end{array}$ & $\begin{array}{r}3.9 \\
4.9 \\
10.9 \\
5.8 \\
8.0 \\
5.4 \\
3.3 \\
4.5\end{array}$ & $\begin{array}{l}0.01 \\
0.02 \\
0.06 \\
0.02 \\
0.04 \\
0.01 \\
0.01 \\
0.01\end{array}$ & $\begin{array}{l}4.4 \\
4.9 \\
8.9 \\
4.1 \\
7.0 \\
3.6 \\
4.9 \\
5.2\end{array}$ & $\begin{array}{l}1.27 \\
2.17 \\
4.56 \\
0.97 \\
2.74 \\
1.48 \\
1.88 \\
1.78\end{array}$ \\
\hline
\end{tabular}


Figure 1. Growth in length (mm) of juvenile red abalone reared under various light and density conditions for 6 months. Each value is the mean of 27 containers of abalone and error bars represent \pm 1 standard error. 


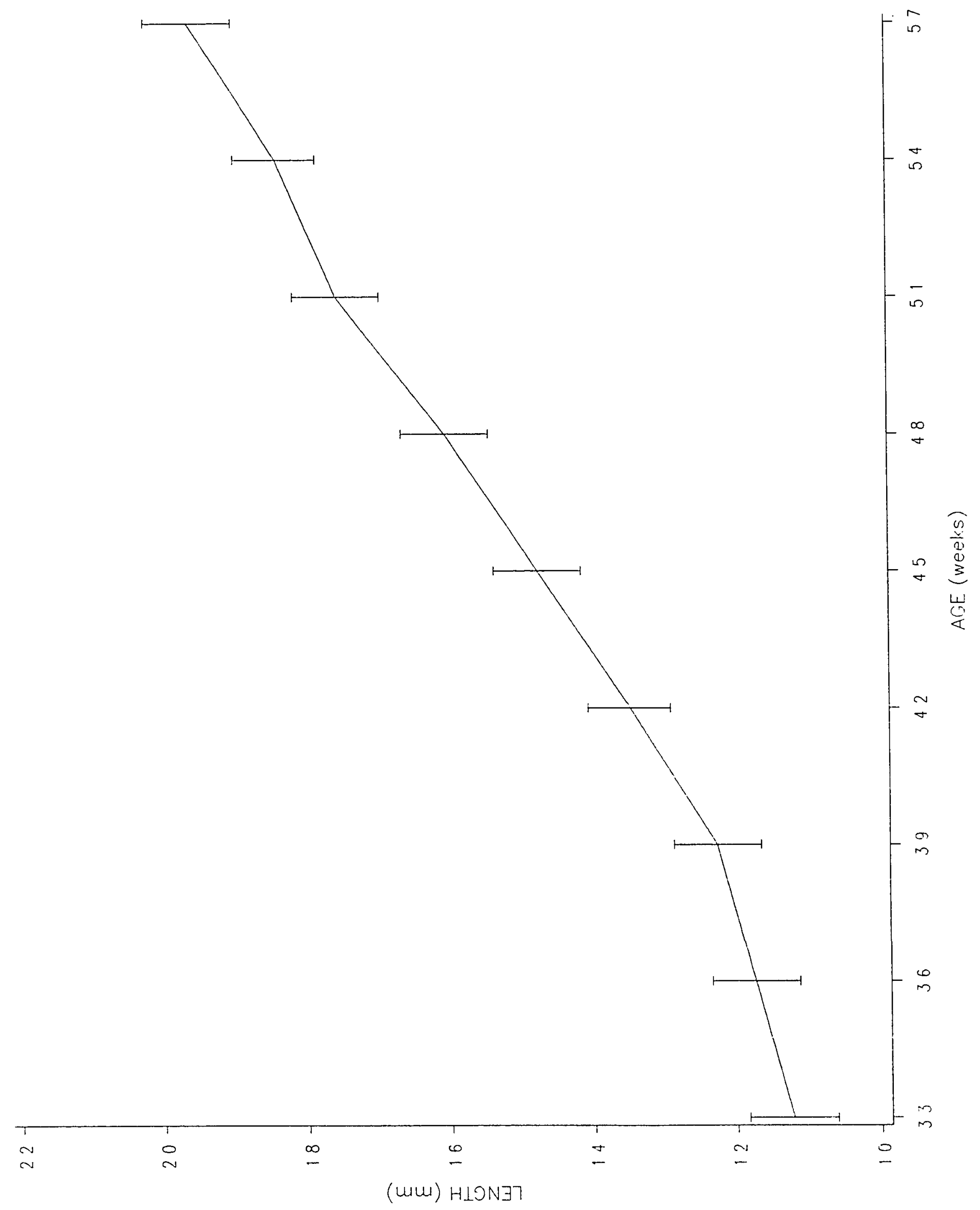


Figure 2. Fit of the von Bertalanffy growth model to juvenile red abalone growth data. Horizontal bars indicate mean lengths measured $(\underline{N}=27)$ and error bars represent \pm 1 standard error. Diamonds signify values predicted by the model. 


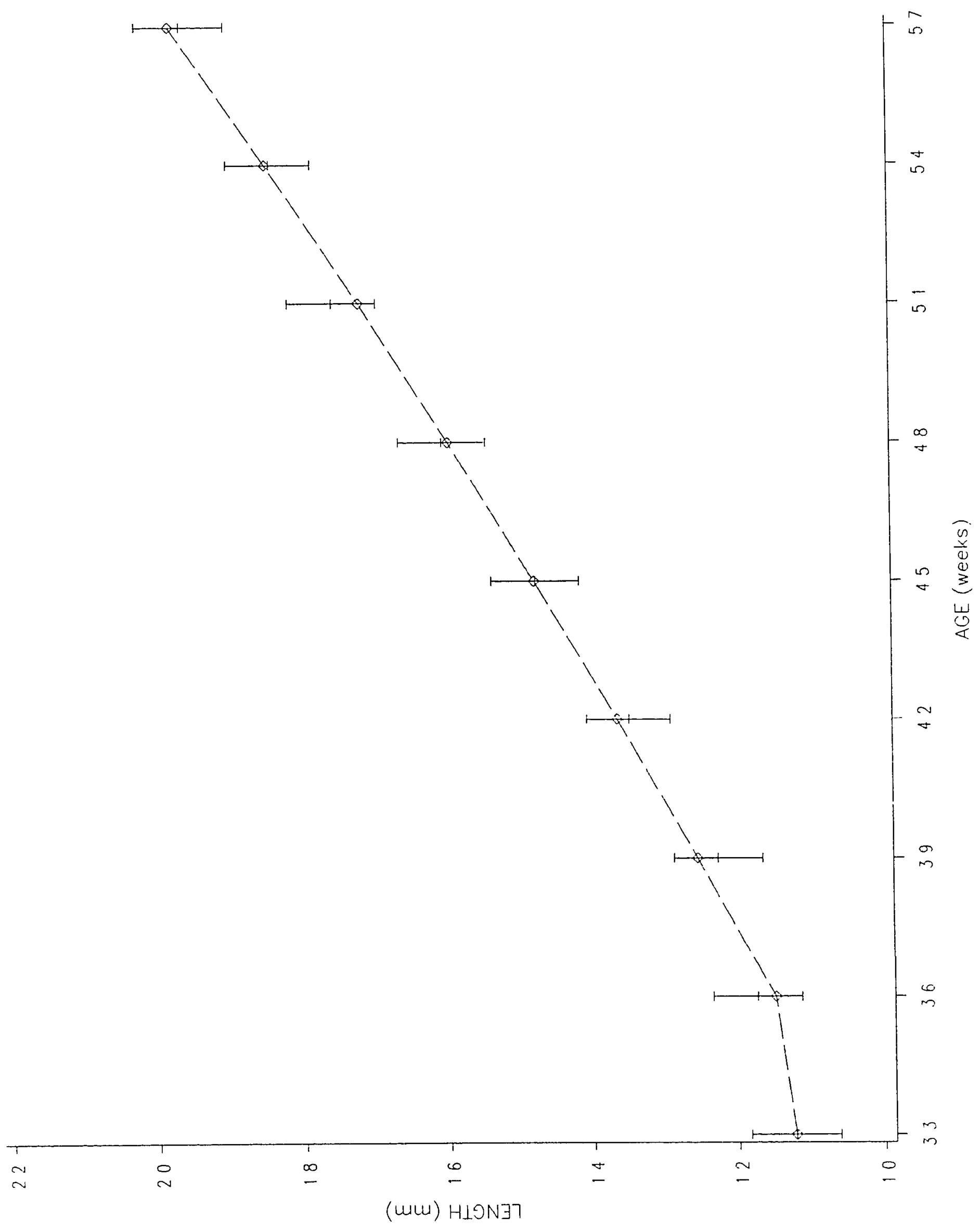


Figure 3. Comparison of growth curves for juvenile red abalone subjected to 3 different light conditions over a 6-month period. Triangles represent mean lengths for abalone reared in containers $(\underline{N}=9)$ kept in $24 \mathrm{~h}$ darkness. Squares represent mean lengths for abalone $(\underline{\mathrm{N}}=9)$ subjected to artificial light. Diamonds signify mean lengths for abalone $(\underline{N}=9)$ maintained in sunlight. 


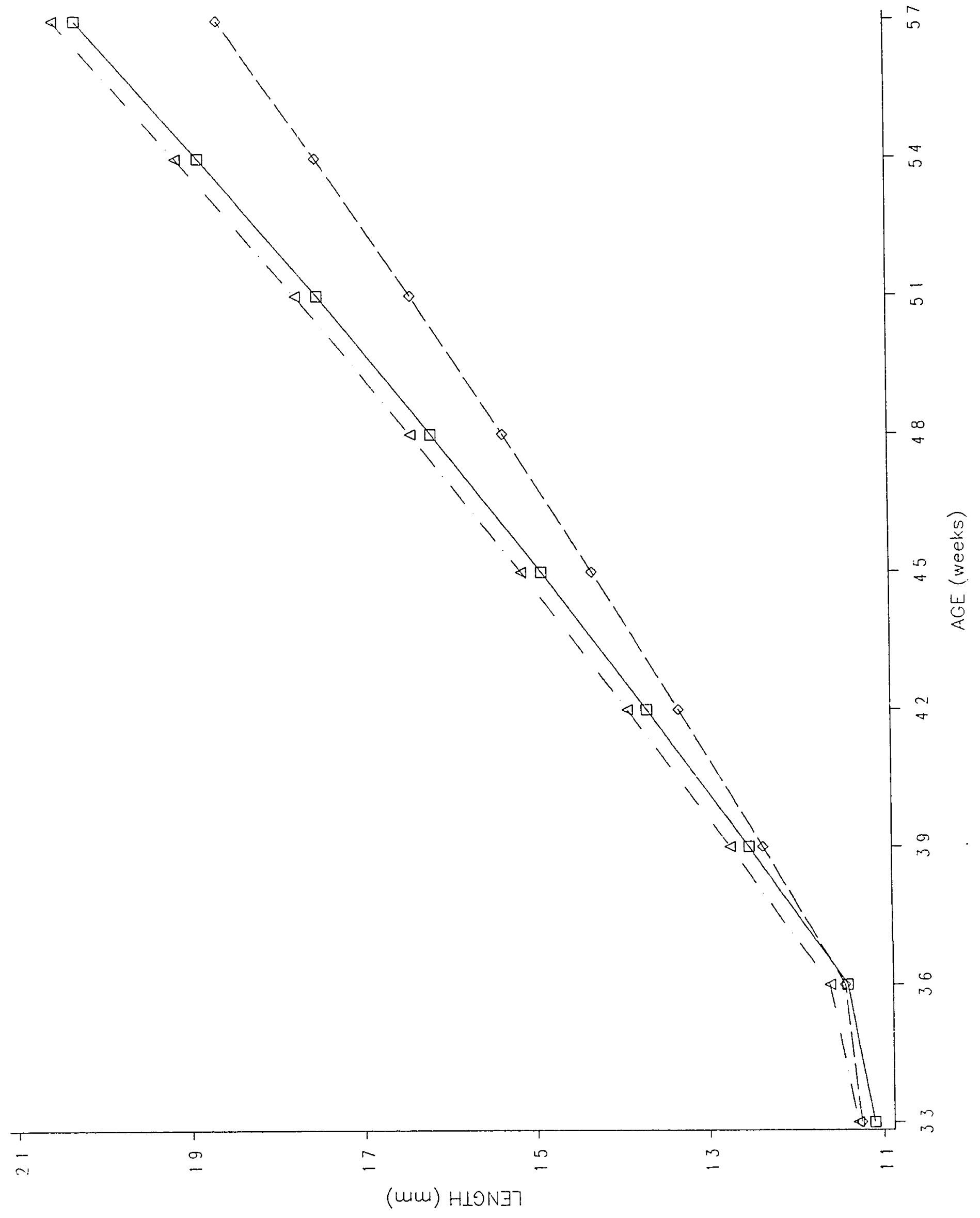


Figure 4. Comparison of growth curves for juvenile red abalone maintained at 3 different rearing densities over a 6-month period. Triangles represent mean abalone lengths for containers $(\underline{N}=$ 9) stocked with 10 abalone each. Diamonds indicate mean abalone lengths for containers $(\underline{N}=$ 9) stocked with 30 abalone each. Squares represent mean abalone lengths for containers ( $\underline{N}=$ 9) stocked with 75 abalone each. 


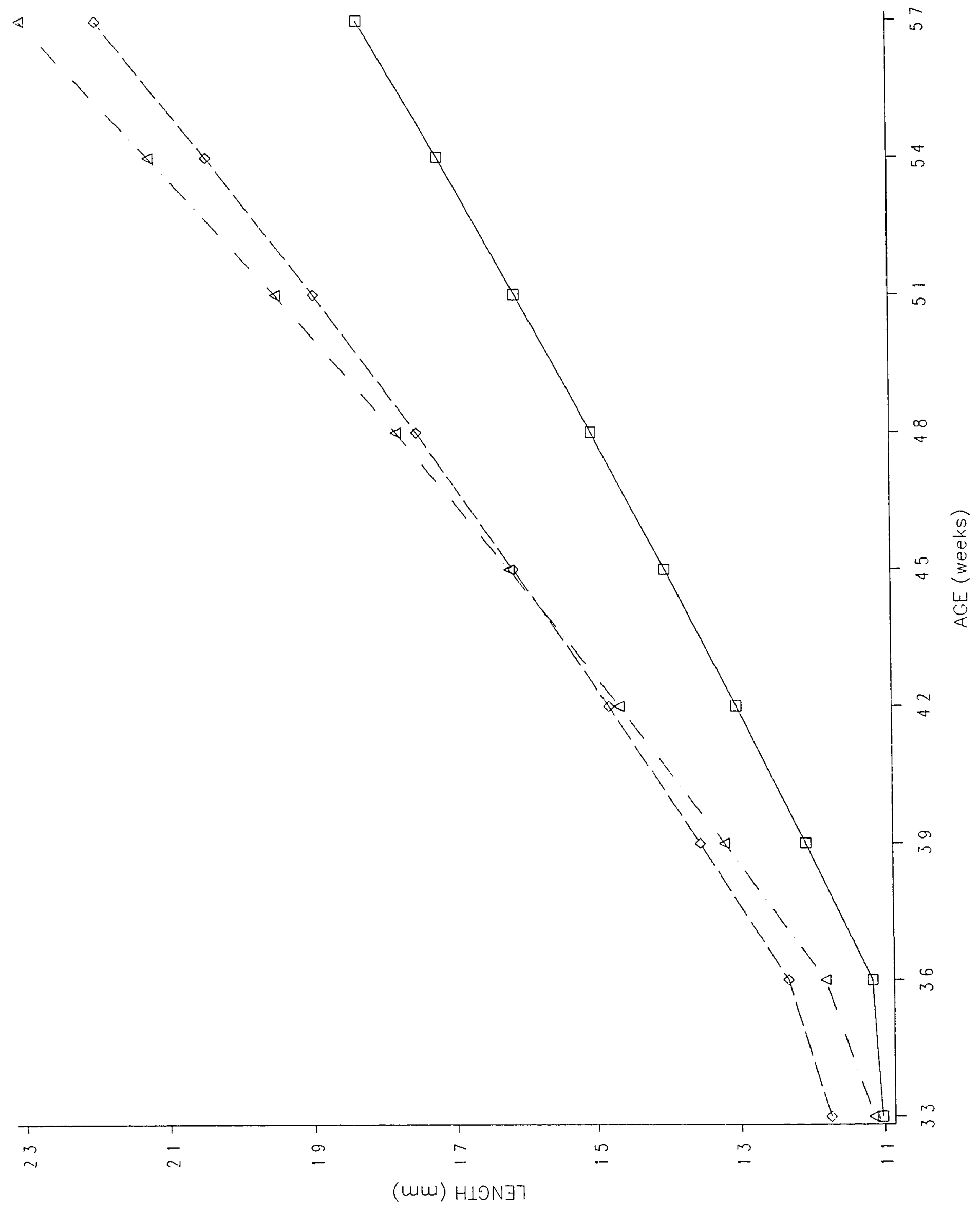


PART III

The Effect of Diet on Growth in Juvenile Red Abalone:

A Comparison of Formulated Feeds and Kelp 


\section{INTRODUCTION}

The red abalone (Haliotis rufescens) is a marine mollusc that lives in shallow waters off the west coast of the United States and Mexico. This species has had high commercial value in California since the mid-nineteenth century. Due largely to over harvesting, habitat loss, and sea otter predation, wild abalone populations have suffered a marked decline over the last 30 years. Consequently, since the 1960s, the red abalone has been a candidate for aquaculture in the western United states.

Due to its slow growth rate, the abalone has limited feasibility as an aquaculture species; thus, selection of foods that are cost effective and that optimize growth rate and conversion efficiency are of particular importance. A great deal of study has been devoted to the nutrition of $\underline{H}$. discus hannai, the most commercially valuable species in Japan (ogino anả onta, 1963; Ogino and Kato, 1964; Uki, et al., 1985a,b, 1986a,b; Uki and Watanabe, 1986). In the United states however, abalone nutrition and assessment of alternative diets have been poorly investigated.

An understanding of the nutritional requirements of an animal is critical to evaluating its potential for aquaculture. Inappropriate food items or nutrient deficient diets can result in poor growth and survival which in turn, 
increase hatchery costs. In addition, some nutritionally complete and palatable foods may be unavailable or too costly to supply. Because the collection and feeding of kelp, the major food item for abalone, is highly labor intensive and its supply can be unreliable during the winter storm months, use of formulated feeds has become increasingly attractive to abalone culturists. Artificial feeds have been studied extensively by Japanese investigators (Ogino and Ohta, 1963; Ogino and Kato, 1964; Sagara and Sakai, 1974; Koike et al., 1979; Uki et al.. $1986 a, b)$, and several abalone culture facilities in Japan successfully raise juvenile and adult $\underline{H}$. discus hannai and H. tuberculata on these feeds (Toole, 1988; Hahn, 1989). Currently, there are no published reports describing use of formulated feeds in the culture of $\underline{H}$. rufescens.

The identification and production of alternative feeds for the red abalone is currently a major constraint to its development as a feasible aquaculture species. This study attempted to evaluate a formulated diet as an alternative food source for hatchery-reared red abalone by testing its palatability and effect on juvenile growth.

\section{MATERIALS AND METHODS}

Hatchery-reared juvenile red abalone (18 months old) 
from Granite Canyon Marine Resources Laboratory (Calif. Dept. of Fish and Game) were used in this experiment. The abalone were fed 1 of 3 diets: a standard hatchery kelp (Macrocystis spp.) diet, or 1 of 2 formulated feed diets supplied by Aquatic Resources (Sebastopol, CA) •

Abalone were held in plastic Rubbermaid food containers (10 animals per container) supplied with seawater at a temperature of $15^{\circ} \mathrm{C} \pm 0.5^{\circ} \mathrm{C}$ and a flow rate of $1.5 \pm 0.5 \mathrm{l} / \mathrm{min}$. Treatments were replicated 6 times for a total of 18 containers. The animals were randomly assigned to treatments, and to containers within treatments. Abalone in the artificial diet groups were acclimated to commercial feeds for 1 month prior to the initiation of the experiment. Abalone in the kelp group were fed ad libitum once per week, and twice per week in the artificial diet groups. Due to quick deterioration of the artificial feed in water, it was necessary to supply fresh food more frequently to these containers.

All abalone were measured (width and length) and weighed every 3 weeks for 6 months. At the end of 6 months, growth rates of abalone in the 3 treatment groups were compared. 


\section{Commercial Feeds}

The commercial feeds included the following nutritional components: protein, $34 \%$; fat $2.5 \%$; fiber $5.5 \%$, calcium $3.5 \%$, phosphorus $1.0 \%$, with vitamins, binder, and ash comprising the remaining portion (percentages are approximations). One commercial feed was enriched with vitamin $c$ to determine if a surplus of this vitamin would enhance abalone growth. Both feeds were morphologically identical, and designed to mimic the appearance of kelp as closely as possible.

\section{Energy Values}

The energy content $(\mathrm{KJ} / \mathrm{g})$ for the formulated diets was determined using bomb calorimetry. Samples of feed were freeze-dried for 24 hours, compressed into pellets weighing approximately $0.5 \mathrm{~g}$, then combusted in a Parr Adiabatic Bomb Calorimeter using benzoic acid as a standard. Heat production was measured, and caloric content assessed by the system computer. Caloric values for Macrocytis spp. were taken from the literature.

\section{statistical Analysis}

Pearson correlation analysis (SAS, 1988) was performed on growth observations to determine if relationships among 
growth parameters (length, width and weight) were linear. since all abalone were measured every 3 weeks, samples from each measurement period were not independent. Consequently, correlation analysis could not be run over all sample periods (Underwood, 1981). Therefore, the correlation was performed on observations from the last measurement period only.

A one-way analysis of variance (ANOVA: SAS, 1988) was conducted to test the effect of the diet treatments on growth. The ANOVin test was considered significant at $\underline{\mathrm{P}} \leq$ 0.05 .

\section{RESULTS}

All 3 diets resulted in similar average growth rates over 6 months (Figure 1). The mean increase in shell length for abalone maintained on the 3 diets was: kelp $-12.65 \mathrm{~mm}$, standara commercial feed - 12.86 mom, and vitamin c enxiched feed $-12.05 \mathrm{~mm}$ (Table 1). Due to high correlation between width, weight and length (Table 2), statistical analysis was only conducted on length measurements. The results of a one-way ANOVA showed no significant difference between the diets $(\underline{P}=0.2769)($ Table 3$)$.

The energy value of kelp (Macrocystis spp.) was taken from Paine and Vadas (1969) who reported an energy content 
of $11.92 \mathrm{~kJ} / \mathrm{g}$. A caloric value for the commercial diets used in this study was determined by bomb calorimetry, which yielded an average energy value of $17.36 \mathrm{KJ} / \mathrm{g}$.

\section{DISCUSSION}

There are several potential advantages to using commercial feeds over kelp. Administration of an artificial diet is much less labor intensive than supplying a kelp diet; the task of harvesting fresh kelp is eliminated and commercial feeds can be administered via automated feeders, whereas kelp must be manually distributed in large quantities to abalone tanks.

Supply of artificial feed is less limited than kelp and readily available all year. Artificial food is also more easily stored. Commercial feeds have a long shelf life, and there is no need for large holding tanks as required for storage of fresh kelp. Aquaculture sites are currently restricted to areas which are close to abundant macroalgae sources. Use of formulated feeds would eliminate this restriction.

Production of artificial feeds has minimal impact on the environment; destruction of marine habitat from harvesting kelp does not occur. Another advantage of artificial foods is the potential for enhanced food 
conversion efficiency, since diet components can be easily manipulated to produce optimal growth.

Because kelp is high in water content and low in protein (Uki, et al., 1986b), an abalone must consume a substantial amount to meet its nutritional requirements. Artificial foods can be formulated to provide a more nutritionally complete diet in a smaller volume. In addition, artificial diets have a higher caloric content than kelp, indicating formulated food may provide a richer source of energy than kelp.

Juvenile abalone can be grown at higher densities if fed artificial food instead of kelp. The extensive surface area required for growth of diatoms and large tank volume required to accommodate kelp are unnecessary when using artificial diets.

The results of this study show that artificial feeds hold promise as an alternative to kelp in the culture of red abalone. Several requirements must be met for an artificial diet to be successful. Among these are: 1) palatability, 2) production of acceptable growth rates, and 3) cost effectiveness. In this experiment, the first 2 requirements were met as juvenile readily accepted the artificial feeds and grew at the same rate as kelp-eating abalone (Table I; Figure I). 
In Japan, it is more economical to supply artificial abalone food rather than kelp since it is less expensive than kelp (Hahn, 1989). In the United States, abalone culturists collect their own kelp, or pay a professional kelp harvester to collect it for them. On the California coast, kelp can be purchased at an average cost of $\$ 0.53 / \mathrm{kg}$ $(\$ 0.24 / 1 b)$ from professional kelp harvesters (Ross Holton, kelp harvester, Cambria, CA, pers. comm.) .

The cost of producing commercially formulated diets for red abalone is difficult to estimate since they are not currently produced on a large scale. One feed supplier (Karen Norman-Boudreau, Aquatic Resources, pers. comm.) estimates the cost at $\$ 1.10-\$ 1.43 / \mathrm{kg}(\$ 0.50-\$ 0.65 / 1 \mathrm{~b})$. However, abalone consume only $1 \%$ to $3 \%$ of their body weight in food per day when eating artificial feeds, as opposed to 5-10\% of their body weight when eating kelp (Karen jorman-Boudreau, pers. comm.), which would partially compensate for the difference in cost per kilogram.

A rough economic comparison can be made on the basis of estimated costs and consumption of kelp versus artificial feed. Feed costs are 2.4 times higher than kelp costs. However, consumption of kelp is 3.8 times higher than consumption of feed. Thus, feed may be more cost effective than kelp in culturing red abalone, assuming other factors 
such as palatability and growth rates are similar.

Development of diets with improved food conversion efficiency would result in lower abalone feeding rates, further reducing the cost of artificial feeds. At present, red abalone feeds are not economically feasible in the United States due to their lack of availability and the relative low cost and abundance of kelp. However, it seems likely that the benefits gained from convenience, decreased labor costs, and good growth rates will ensure widespread usage of artificial diets if they are proven effective on a large scale and become readily available.

Although artificial feeds hold potential as appropriate foods for red abalone, more research is necessary to resolve problems that currently exist with formulated diets. Feeding activity in abalone can be affected by a variety of factors (e.g., Koike, et al., 1979) leading to erratic eating patterns. Consequentiy, food may sit in the tank for several hours before it is eaten. When using artificial diets, this may lead to nutrient leaching and deterioration of water quality. Also, the relatively fast deterioration of artificial feeds used in this study necessitated more frequent feeding and cleaning of containers. This could considerably increase labor costs at an abalone culture facility. This problem can be solved by adding more binder 
to the diet during formulation; this may, however, result in a more expensive abalone feed.

Abalone used in this study were initially 1.7 to $1.8 \mathrm{~mm}$ and were fully weaned from diatoms. Preliminary results from another study suggest that red abalone in the $10 \mathrm{~mm}$ size range grow significantly better on a formulated diet than on a kelp diet (Carolyn Friedman, CDFG, pers. comm.) . At this size, abalone are in the weaning stage, during which they change their diet from diatoms to kelp. currently available artificial feeds may be most advantageous for use in cultured abalone during this transitional phase. The

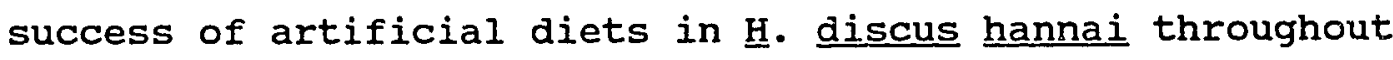
its commercial life cycle, however, indicate that diets may be formulated for $\underline{H}$. rufescens that will be useful for all the stages of development that occur before marketable size is reached.

\section{IITERATURE CITED}

Hahn, K.0., 1989. Handbook of Culture of Abalone and Other Marine Gastropods. CRC Press, Inc., Florida, 348pp. Koike, Y., Flassch, J. and Mazurier, J., 1979. Biological and ecological studies on the propagation of the ormer, Haliotis tuberculata Linnaeus. II. Influence of food and density on the growth of juveniles. La mer, 
$17: 43-52$.

Ogino, C. and Ohta, E., 1963. Studies on the nutrition of abalone. I. Feeding trials of abalone, Haliotis discus Reeve, with artificial diets. Bull. Jpn. Soc. Sci. Fish., $29(7): 691$.

Ogino, C. and Kato, N., 1964. Studies on the nutrition of abalone. II. Protein requirements for growth of abalone, Haliotis discus. Bull. Jpn. Soc. Sci. Fish., $30(6): 523$.

Paine, R.T. and Vadas, R.L., 1969. Calorific values of benthic marine algae and their postulated relation to invertebrate food preference. Mar. Biol., 4:79-86. Sagara, J. and Sakai, K., 1974. Feeding experiments of juvenile abalones with four artificial diets. Bull. Tokai Reg. Fish. Res. Lab., $77: 1$.

SAS Institute Inc., 1988. SAS/STAT User's Guide, release 6.03 edition. Cary, ÑC, 1028pp.

Toole, C., 1988. Report of a study trip to Japan. I. Molluscan aquaculture and fisheries. Calif. Sea Grant Coll. Working Paper No. P-T-48. Univ. Calif. Coop. Ext. , Eureka, CA, 68pp.

Uki, N., Kemuyama, A. and Watanabe, T., 1985a. Development of semipurified test diets for abalone. Bull. Jpn. Soc. Sci. Fish., 51(11):1825. 
Uki, N., Kemuyama, A. and Watanabe, T., 1985b. Nutritional evaluation of several protein sources in diets for abalone Haliotis discus hannai. Bull. Ipn. Soc. Sci. Fish., $51(11): 1835$.

Uki, N., Kemuyama, A. and Watanabe, T., 1986a. Optimum protein levels in diets for abalone. Bull. Jpn. Soc. Sci. Fish., $52(6): 1005$.

Uki, N., Sugiura, M. and Watanabe, T., 1986b. Requirement of essential fatty acids in the abalone Haliotis discus hannai. Bull. Jpn. Soc. Sci. Fish., 52(6):1013.

Uki, N. and Watanabe, T., 1986. Effect of heat-treatment of dietary protein sources on their protein quality for abalone. Bull. Jpn. Soc. Sci. Fish., 52(7):1199.

Underwood, A.J., 1981. Techniques of analysis of variance in experimental marine biology and ecology. Oceanogr. Mar. Biol. Ann. Rev., 19:513-605. 
Table 1. Growth in shell length of juvenile abalone maintained on 1 of 3 diets for 6 months: kelp (K), standard feed (S), or vitamin $C$ enriched (VC). Measurements represent mean shell lengths from 5 containers per treatment with 10 abalone per container. Standard deviations are reported in parentheses following the means. Abalone were 42 weeks of age initially, and 66 weeks old at the end of the experiment. $(\underline{\mathrm{N}}=5)$.

\begin{tabular}{|c|c|c|c|}
\hline Diet & $\begin{array}{c}\text { Initial Mean Length } \\
(\mathrm{mm})\end{array}$ & $\begin{array}{c}\text { Final Mean Length } \\
(\mathrm{mm})\end{array}$ & $\begin{array}{c}\text { Mean Growth } \\
(\mathrm{mm})\end{array}$ \\
\hline $\begin{array}{l}\mathrm{K} \\
\mathrm{S} \\
\mathrm{VC}\end{array}$ & $\begin{array}{ll}18.66 & (3.022) \\
17.71 & (1.815) \\
17.63 & (2.537)\end{array}$ & $\begin{array}{ll}31.31 & (3.516) \\
30.57 & (2.345) \\
29.68 & (2.239)\end{array}$ & $\begin{array}{l}12.65 \\
12.86 \\
12.05\end{array}$ \\
\hline
\end{tabular}


Table 2. Correlation of lengthi, width, and weight variables for juvenile red abalone at 66 weeks of age. Values for the Pearson correlation coefficient, $\underline{r}$, are presented relating length, width and weight. $(\underline{N}=150)$.

\begin{tabular}{lccc}
\hline Variable & Length & Width & Weight \\
\hline Length & 1 & $-1-$ & -- \\
Width & 0.9821 & 1 & -- \\
Weight & 0.9606 & 0.9599 & 1 \\
\hline
\end{tabular}


Table 3. Analysis of variance test comparing differences in abalone growth among the following 3 diets fed to juvenile abalone for 6 months: kelp, standard feed, vitamin $C$ enriched feed.

\begin{tabular}{|c|c|c|c|c|c|}
\hline Source & $\mathrm{DF}$ & SS & MS & $\mathbf{F}$ & $\mathrm{P}$ \\
\hline $\begin{array}{l}\text { Diet } \\
\text { Error }\end{array}$ & $\begin{array}{r}2 \\
12\end{array}$ & $\begin{array}{l}17.91 \\
75.06\end{array}$ & $\begin{array}{l}8.95 \\
6.25\end{array}$ & $\begin{array}{c}1.42 \\
--\end{array}$ & $\begin{array}{c}0.2769 \\
-\end{array}$ \\
\hline
\end{tabular}


Figure 1. Growth of juvenile abalone maintained on a kelp diet for 1 of 2 formulated feed diets for 6 months: kelp (circles), standard feed (squares), or vitamin $c$ enriched feed (triangles). 


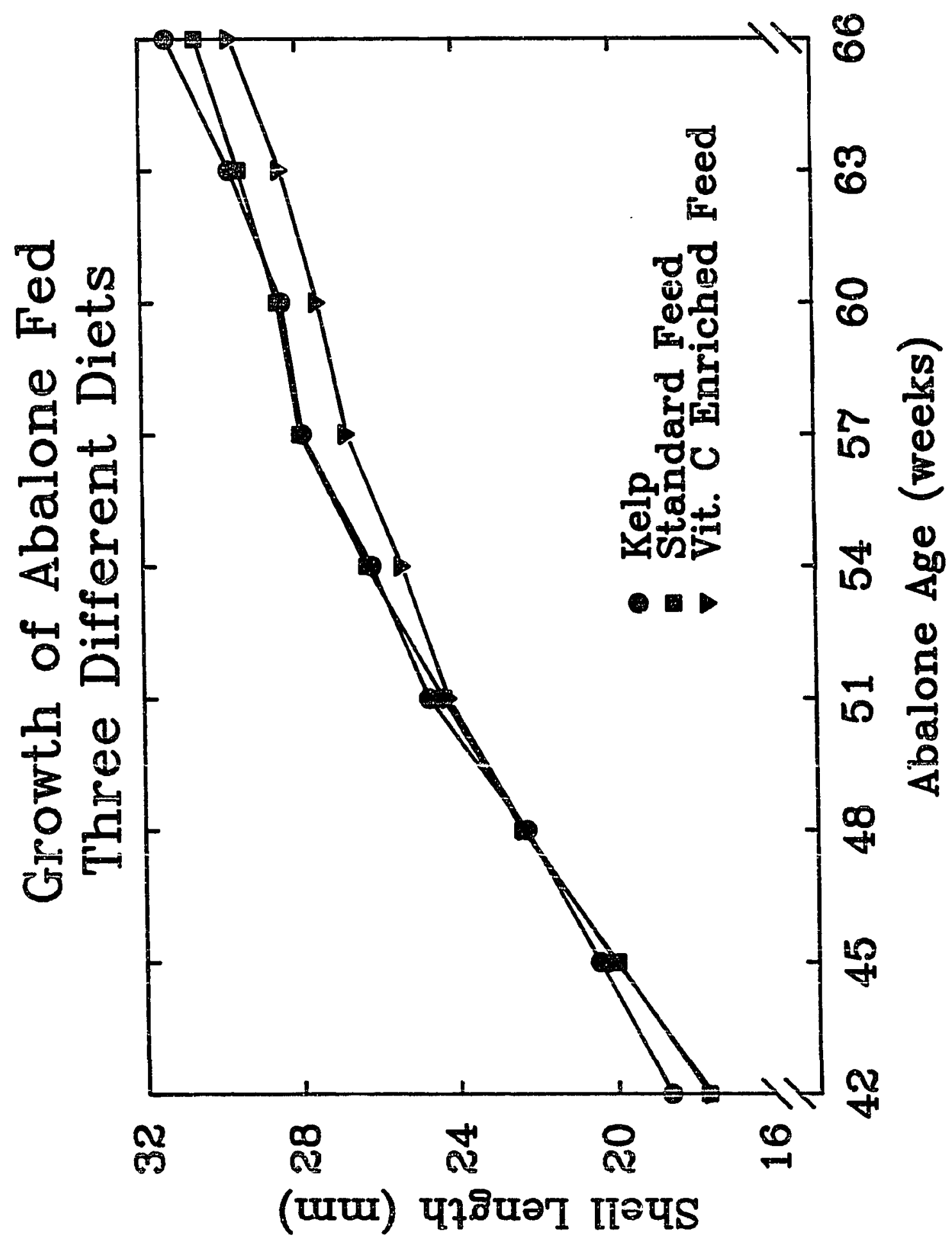




\section{ACKNOWLEDGEMENTS}

I would like to thank the California Department of Fish \& Game (CDFG), Earl and Ethel Meyers Foundation, David Packard Foundation, and Conchologists Society of America for providing financial support.

I am very grateful to Earl Ebert (CDFG) for sparking my interest in abalone aquaculture and making it possible for me to conduct my experiments at the CDFG Granite Canyon Marine Resources Laboratory, and also for working hard to secure funding for my research.

I would like to acknowledge the director and staff of Granite Canyon Marine Resources Laboratory for their help and cooperation: Bob Lee, Deb Wilson-Vandenburg, Michael Harris, Carol Wagner, Jim Lytle, and Susan McBride. I would also like to thank Karen Norman-Boudreau of Aquatic Resources for supplying her abalone food to me, and Karen Gonzalez ố thè U.S. Fish̆ a Wildifie Service for writing a data entry program for me.

Many thanks to Dr. J. Nybakken (Moss Landing Marine Labs) for acting as my graduate advisor, and to Earl Ebert, Dr. M. Foster (Moss Landing Marine Labs), and Dr. J. Nybakken for serving on my thesis committee.

I would like to express my gratitude to my friend and fellow graduate student, Susan McBride, for her support and 


\section{PLEASE NOTE}

Page(s) not included with original material and unavailable from author or university. Filmed as received. 